\title{
The Advantages of EPR Spectroscopy in Exploring Diamagnetic Metal Ion Binding and Transfer Mechanisms in Biological Systems
}

\author{
Shelly Meron, Yulia Shenberger and Sharon Ruthstein *(D) \\ Department of Chemistry and the Institute of Nanotechnology and Advanced Materials (BINA), \\ Bar-Ilan University, Ramat-Gan 5290002, Israel; merondvash@gmail.com (S.M.); levjulia86@gmail.com (Y.S.) \\ * Correspondence: Sharon.ruthstein@biu.ac.il; Tel.: +972-3-738-4329
}

check for updates

Citation: Meron, S.; Shenberger, Y.;

Ruthstein, S. The Advantages of EPR Spectroscopy in Exploring

Diamagnetic Metal Ion Binding and

Transfer Mechanisms in Biological

Systems. Magnetochemistry 2022, 8, 3.

https://doi.org/10.3390/

magnetochemistry 8010003

Academic Editors: Angeliki

Giannoulis and Dinar Abdullin

Received: 21 November 2021

Accepted: 22 December 2021

Published: 26 December 2021

Publisher's Note: MDPI stays neutral with regard to jurisdictional claims in published maps and institutional affiliations.

Copyright: (C) 2021 by the authors. Licensee MDPI, Basel, Switzerland. This article is an open access article distributed under the terms and conditions of the Creative Commons Attribution (CC BY) license (https:// creativecommons.org/licenses/by/ $4.0 /)$.

\begin{abstract}
Electron paramagnetic resonance (EPR) spectroscopy has emerged as an ideal biophysical tool to study complex biological processes. EPR spectroscopy can follow minor conformational changes in various proteins as a function of ligand or protein binding or interactions with high resolution and sensitivity. Resolving cellular mechanisms, involving small ligand binding or metal ion transfer, is not trivial and cannot be studied using conventional biophysical tools. In recent years, our group has been using EPR spectroscopy to study the mechanism underlying copper ion transfer in eukaryotic and prokaryotic systems. This mini-review focuses on our achievements following copper metal coordination in the diamagnetic oxidation state, $\mathrm{Cu}(\mathrm{I})$, between biomolecules. We discuss the conformational changes induced in proteins upon $\mathrm{Cu}(\mathrm{I})$ binding, as well as the conformational changes induced in two proteins involved in $\mathrm{Cu}(\mathrm{I})$ transfer. We also consider how EPR spectroscopy, together with other biophysical and computational tools, can identify the $\mathrm{Cu}(\mathrm{I})$-binding sites. This work describes the advantages of EPR spectroscopy for studying biological processes that involve small ligand binding and transfer between intracellular proteins.
\end{abstract}

Keywords: copper cycle; copper metabolism; CW-EPR; DEER; EPR spectroscopy

\section{Introduction}

Transition metals are key nutrients for almost all organisms, given their roles in critical biochemical pathways, such as respiration, photosynthesis, and nitrogen fixation [1-3]. However, unlike other biomolecules, metals cannot be synthesized in the cell and, hence, must be obtained from the environment. Once acquired, metals must be routed to the correct intracellular destination to prevent deleterious side-reactions or non-specific chelation by other cellular components [4-9]. Consequently, most organisms contain metalloregulator proteins that help maintain metal homeostasis. Considering the ubiquitous presence of metals in the cell, it follows that even small errors in biometal regulation are likely to impact cell function, growth, and survival. It is, thus, of tremendous importance to understand each step in the cycle of metal uptake, usage, and clearance to achieve a fundamental understanding of the sources of metal homeostasis disruption [10-12].

The binding of diamagnetic metal ions, such as $\mathrm{Zn}(\mathrm{II}), \mathrm{Mg}(\mathrm{II}), \mathrm{Cu}(\mathrm{I})$ and $\mathrm{Ag}(\mathrm{I})$, to proteins, has been mostly studied by nuclear magnetic resonance (NMR) and X-ray absorbance fine structure (EXAFS) spectroscopy, techniques that can provide information on the metal coordination site at the molecular level, specifically those atoms and residues involved in metal binding [12-16]. While electron paramagnetic resonance (EPR) spectroscopy cannot provide information on residues directly involved in the coordination of diamagnetic metal ions, it can, however, probe the dynamics and conformational changes in a biomolecule in solution upon metal ion binding, thereby providing important structural and functional information on the biomolecule as a function of metal coordination. These are useful data, especially for studying the biological processes involved in metal coordination and transfer between various proteins. In recent years, we have been applying EPR spectroscopy to 
study $\mathrm{Cu}(\mathrm{I})$ binding and the mechanism of $\mathrm{Cu}(\mathrm{I})$ transfer in eukaryotic and prokaryotic systems [11,17].

\subsection{Copper Homeostasis}

Copper is an essential trace metal for living organisms. Many proteins that participate in cellular respiration, anti-oxidant defense, neurotransmitter biosynthesis, connective tissue biosynthesis, and pigment formation use copper as their prosthetic active group [2,4]. However, owing to its redox activity, copper can also be highly toxic when present in the free ionic form. Free copper can participate in Fenton-like chemical reactions to generate highly toxic hydroxyl radicals from hydrogen peroxide and superoxide [2,7]. Therefore, both prokaryotic and eukaryotic systems have developed highly regulated mechanisms for copper transport and intracellular distribution to allow only negligible changes (subfemtomolar concentrations) in the intracellular copper levels $[10,11,18]$.

In eukaryotic systems, it is known that copper is consumed and delivered to the cell by the main copper transporter (Ctr1) in the $\mathrm{Cu}(\mathrm{I})$ oxidation state $[19,20]$. When $\mathrm{Cu}(\mathrm{I})$ is transferred into the cell, specific $\mathrm{Cu}$-recognizing chaperones are responsible for its delivery to specific cellular pathways (Figure 1A) [2,21-23]. These chaperones include Atox1, which delivers copper to the copper-transporting ATPases in the Golgi, CCS, required for copper incorporation into cytoplasmic $\mathrm{Cu} / \mathrm{Zn}$ superoxide dismutase, as well as Cox17, Sco1, and Sco2, which deliver copper to mitochondrial cytochrome c oxidase [21-26].

\section{A}

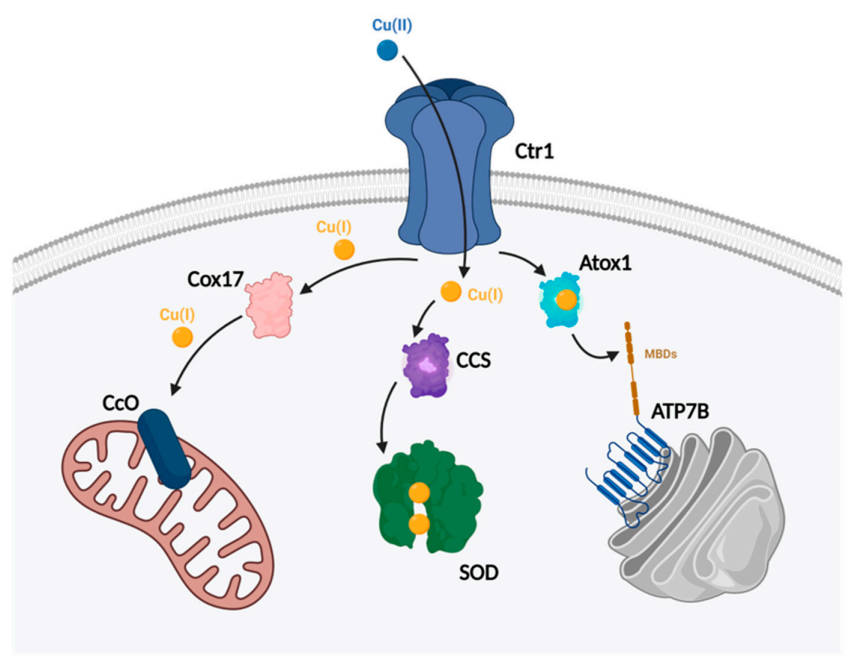

B

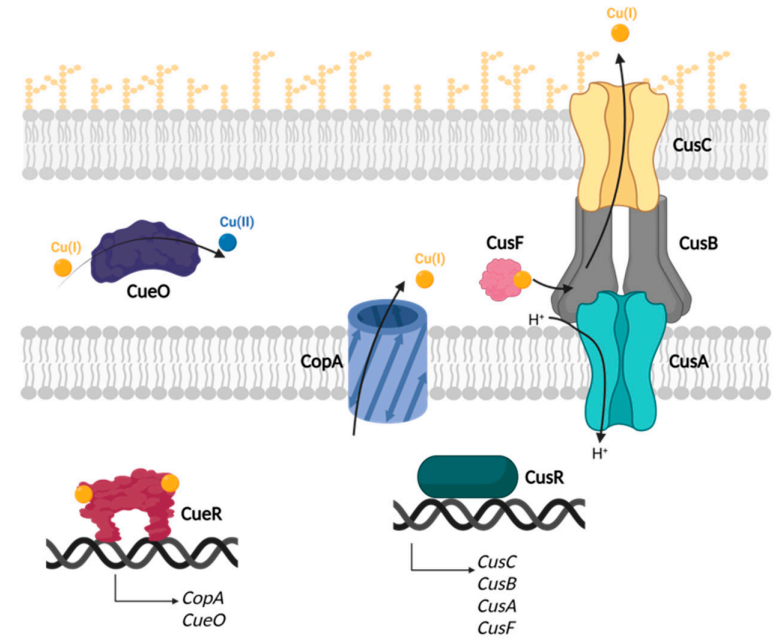

Figure 1. Copper transfer pathways in (A) a human cell and (B) the bacterium Escherichia coli. $\mathrm{Cu}(\mathrm{I})$ is denoted in yellow, whereas $\mathrm{Cu}(\mathrm{II})$ is in blue. 
However, in prokaryotic systems, copper regulation is more sophisticated, since such microorganisms can encounter changes in their environment. In Gram-negative bacteria, four different mechanisms regulate cellular $\mathrm{Cu}(\mathrm{I})$ (Figure 1B) [10]. The first mechanism involves proteins that export copper from the cytoplasm. Such proteins are $\mathrm{P}_{1 \mathrm{~B}}$-type ATPase membrane transporters responsible for pumping $\mathrm{Cu}(\mathrm{I})$ ions from the plasma membrane to the periplasmic space. Examples of these proteins include Escherichia coli (E. coli) CopA and Mycobacterium tuberculosis CtpV [18,27]. A second process relies on proteins that export copper from the periplasm. These protein complexes are located in the periplasm, where they control the transfer of $\mathrm{Cu}(\mathrm{I})$ ions from the periplasm to the extracellular medium. In $E$. coli, the CusABC complex and its metallochaperone CusF are responsible for mediating copper export across the inner and outer membranes, exploiting the proton motive force. This tetrameric complex comprises an inner membrane proton-substrate carrier (CusA) and an outer membrane pore (CusC), connected by the linker protein CusB, and the small CusF metallochaperone $[28,29]$. The third mechanism used to regulate copper levels in the cell employs multi-copper oxidases, which are responsible for reducing the potential for coppermediated damage by oxidizing $\mathrm{Cu}(\mathrm{I})$ to $\mathrm{Cu}(\mathrm{II})$, which is less toxic to the cell. Bacterial multi-copper oxidases known to confer copper tolerance include E. coli and Salmonella typhimurium CueO, and M. tuberculosis $\mathrm{MmeO}$ [30,31]. The last mode of regulation relies on proteins that act as copper sensors. These correspond to gene regulatory proteins, coined metalloregulatory proteins, or metal sensor proteins that tolerate the metal transfer rate [32]. These specialized "metal receptor" proteins have evolved metal coordination sites that "sense" specific metal ion(s) by forming specific coordination complexes that can present zeptomolar $\left(\sim 10^{-21} \mathrm{M}\right)$ level affinities. This, in turn, serves to either activate or inhibit DNA binding or transcription activation, leading to the expression of genes that mediate what must be an exquisitely selective adaptive response [33-37]. In E. coli, the Cu(I) metal sensor CueR activates the transcription of CopA and CueO metalloproteins [36-39].

$\mathrm{Cu}(\mathrm{I})$-binding sites in proteins that are involved in the cellular copper regulation system are characterized by cysteine- and methionine-based segments, such as CXXC or MXXMXXM (where X stands for any amino acid). Some proteins also involve histidine residues in their coordination sites [40-43]. In general, $\mathrm{Cu}(\mathrm{I})$ ions are mostly found in a trigonal coordination with sulfur and nitrogen atoms $[43,44]$.

\subsection{EPR Spectroscopy}

EPR spectroscopy is an experimental technique for characterizing the energy levels of a system with unpaired electrons in an externally applied magnetic field. The separation of these energy levels as a function of the magnetic field depends on the type of the unpaired electron, and on the nature and structure of its surroundings. EPR has emerged as a preferred tool for resolving the structural properties of many proteins, such as metalloproteins, membrane proteins, and intrinsically disordered proteins [45-55], which cannot be studied by traditional biophysical methods. The power of EPR lies in its sensitivity to both atomic level changes and conformational changes at the nanoscale [56-58]. EPR requires paramagnetic species, such as free radicals or paramagnetic metal ions such as $\mathrm{Cu}(\mathrm{II}), \mathrm{Mn}(\mathrm{II})$, Gd(III), and Fe(III). Nitroxide radicals have been used for many years as paramagnetic species for studying biological systems $[49,57,59]$. Such spin labels are stable and since a great variety of functional groups can be introduced, these spin labels can be substituted into different molecules at a variety of sites. In our studies, we employ the site-directed spin labeling (SDSL) method developed by the Hubbell group [59-61]. The power of SDSL lies in its ability to attach a spin-label to an amino acid, usually cysteine residue, by binding to thiol reactive groups. Some nitroxide spin-labels suited for SDSL are the maleimide spin-label (MSL) [13], the methanethiosulfonate group (MTSSL), or the iodoacetamide group (IA-PROXYL) [62]. MTSSL (Figure 2) is the most widely used spin-label, owing to its high selectivity to thiol groups, its stability in solution, and the fact that it causes minimal to no perturbation to the protein or its function $[59,60]$. Other spin-labels that are often used in SDSL are the trityl, Gd(III), Mn(II), and the Cu(II) based spin-labels [63-69]. 


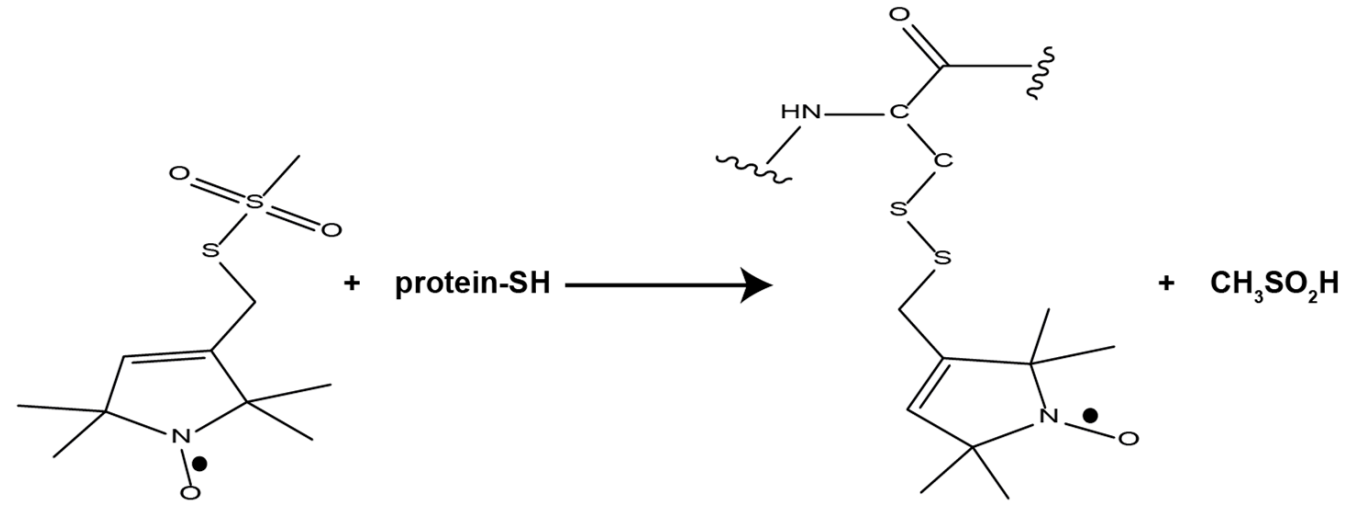

Methanesulfonothioate spin-label (MTSSL)

Figure 2. Spin labeling of a cysteine residue with methanesulfonthioate.

In a continuous wave (CW) EPR experiment, CW-EPR spectra are collected by placing a sample into a constant microwave frequency, and varying the magnetic field until the resonance condition is satisfied [56,70]. The CW-EPR spectrum reports on all the interactions present between the paramagnetic center and nearby magnetic sites, at the close environment of the paramagnetic center (molecular level type of information). When nitroxide spin-labels are used, changes in line shape (owing to changes in dynamics), line width $(\Delta \mathrm{B})$, hyperfine (electron-nuclear interaction) $\left(\mathrm{a}_{\mathrm{N}}\right)$, and g-values can be probed. The extent of such changes depends on the type of the spin-label and the strength of its interaction with the environment. In a pulse EPR experiment, the magnetic field is kept fixed, and a set of microwave pulses are generated to isolate an individual interaction that contributes to the shape and behavior of the CW-EPR spectrum [58]. One such interaction is the dipolar interaction between two paramagnetic centers, which can report on nanometer distances (usually at a range of $2.0-10.0 \mathrm{~nm}$ ) between two paramagnetic sites. The most common approaches to acquire nanoscale structural information are double electron electron resonance (DEER), also referred to as pulsed electron double resonance (PELDOR) [51,71-75], Double Quantum Coherence (DQC) [76-78], and relaxation induced dipolar modulation enhancement (RIDME) [79,80]. In all experiments, the Fourier transform (FT) spectra yield characteristic lineshapes and splittings that may be analyzed for distances and distance distributions.

The combination of CW and pulsed EPR with SDSL has become widely used in biophysical research, where an electron spin introduced into diamagnetic proteins provides information on their local environment and on the mobility of the protein domain. When multiple spin labels are attached, distance distributions between them can be derived [45-55].

This review provides several case studies that demonstrate how EPR spectroscopy can be utilized to follow the diamagnetic metal coordination, with the focus of copper in the $\mathrm{Cu}(\mathrm{I})$ oxidation state, to biomolecules. We will discuss conformational changes induced in proteins upon $\mathrm{Cu}(\mathrm{I})$ binding, as well as conformational changes induced in two proteins involved in $\mathrm{Cu}(\mathrm{I})$ transfer. We will also discuss how EPR spectroscopy, together with other microscopy and spectroscopy tools, as well as molecular dynamic (MD) simulations, can identify $\mathrm{Cu}(\mathrm{I})$-binding sites. Finally, this review presents the advantages of using EPR spectroscopy to study cellular processes involved in small ligand binding and transfer.

\section{Case Studies}

\subsection{Following Conformational Changes in Biomolecules upon Metal Binding}

Methionine-rich sequence motifs are found in several proteins involved in copper metabolism. These "Mets motifs" are capable of binding Cu(I) with micromolar affinity. Although they are highly selective, Mets motifs lack sequence specificity, aside from requiring three methionine amino acids [42,44]. In eukaryotes, methionine motifs are present in the Ctr1 family of membrane transporters, particularly in the N-terminal domain 
of these membrane proteins. In prokaryotes, these motifs are found in chromosome- and plasmid-encoded copper proteins, such as those encoded by the pco (plasmid-borne copper resistance), cop (copper resistance) and cue (copper export) operons. These gene products include PcoC from the pco operon [81], CopA and CopC from the cop operon, in addition to many others [82,83]. Mets motifs have been found to bind $\mathrm{Ag}(\mathrm{I})$ and $\mathrm{Cu}(\mathrm{I})$ ions $[13,44]$. Some studies have shown that the function of many proteins involved in $\mathrm{Cu}(\mathrm{I})$ transportation can be inhibited by coordination to $\mathrm{Ag}(\mathrm{I})$. We, therefore, used EPR spectroscopy to study the coordination of $\mathrm{Ag}(\mathrm{I})$ vs. $\mathrm{Cu}(\mathrm{I})$ to a general Mets motif, MTGMHKMS (named here Met) [13]. To follow the conformational changes, we added two cysteine residues at the termini of the peptide and spin-labeled it with MTSSL to generate R1MTGMHKMSR1 (R1 often refers to MTSSL attached to cysteine residue).

The CW-EPR spectra recorded at room temperature (RT) identified changes in the line width $(\Delta \mathrm{B})$ and hyperfine value $\left(\mathrm{a}_{\mathrm{N}}\right)$ as a function of $\mathrm{Cu}(\mathrm{I})$ and $\mathrm{Ag}(\mathrm{I})$ coordination (Figure 3). While a decrease in the hyperfine value as well as in the line width was detected upon $\mathrm{Cu}(\mathrm{I})$ coordination, increases in both values were observed with $\mathrm{Ag}(\mathrm{I})$. The difference in the behavior of the two metal ions shows that CW-EPR using SDSL can detect metal ion binding to a biomolecule, even in a random-coil short peptide, with comparable high mobility. Moreover, CW-EPR can distinguish between the binding of different metal ions.
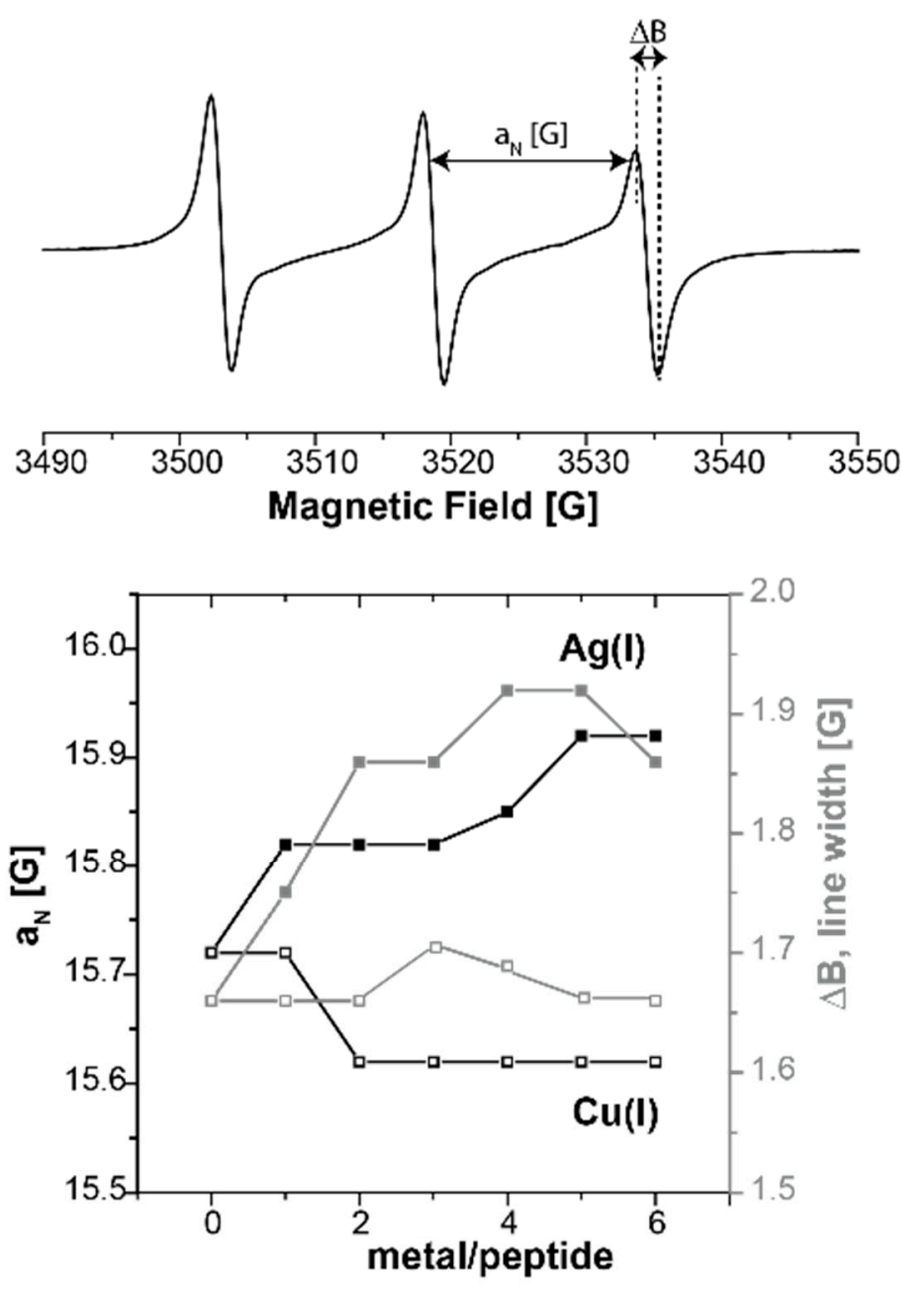

Figure 3. $\mathrm{Cu}(\mathrm{I})$ and $\mathrm{Ag}(\mathrm{I})$ induce different dynamic changes in the Mets motif. Top: Room temperature $\mathrm{CW}$-EPR spectrum of a $\mathrm{Cu}(\mathrm{I})$ :Met ratio of $4: 1$. Bottom: $\triangle \mathrm{B}$ is the line width measured and $\mathrm{a}_{\mathrm{N}}$ is the isotropic hyperfine coupling measured. Changes in $\Delta \mathrm{B}$ and $\mathrm{a}_{\mathrm{N}}$ as a function of $\mathrm{Cu}(\mathrm{I})$ and $\mathrm{Ag}(\mathrm{I})$ binding are shown. Adapted from reference [13]. 
Figure 4 shows the DEER signals, the corresponding FT spectra, and distance distribution functions for R1MTGMHKMSR1. For the Mets motif alone, the distance distribution was found to be $2.6 \pm 1.0 \mathrm{~nm}$. In the presence of $\mathrm{Cu}(\mathrm{I})$, the distribution was similar, whereas in the presence of $\mathrm{Ag}(\mathrm{I})$, a slightly narrower distance distribution function of $2.4 \pm 0.6 \mathrm{~nm}$ was detected. This is also clear in a more resolved FT spectrum of Met + Ag(I), suggesting that the structure of Met is less flexible in the presence of $\mathrm{Ag}(\mathrm{I})$. Here, the DEER data did not detect large changes in the distance distribution function, owing to the large flexibility of the short peptide.

A
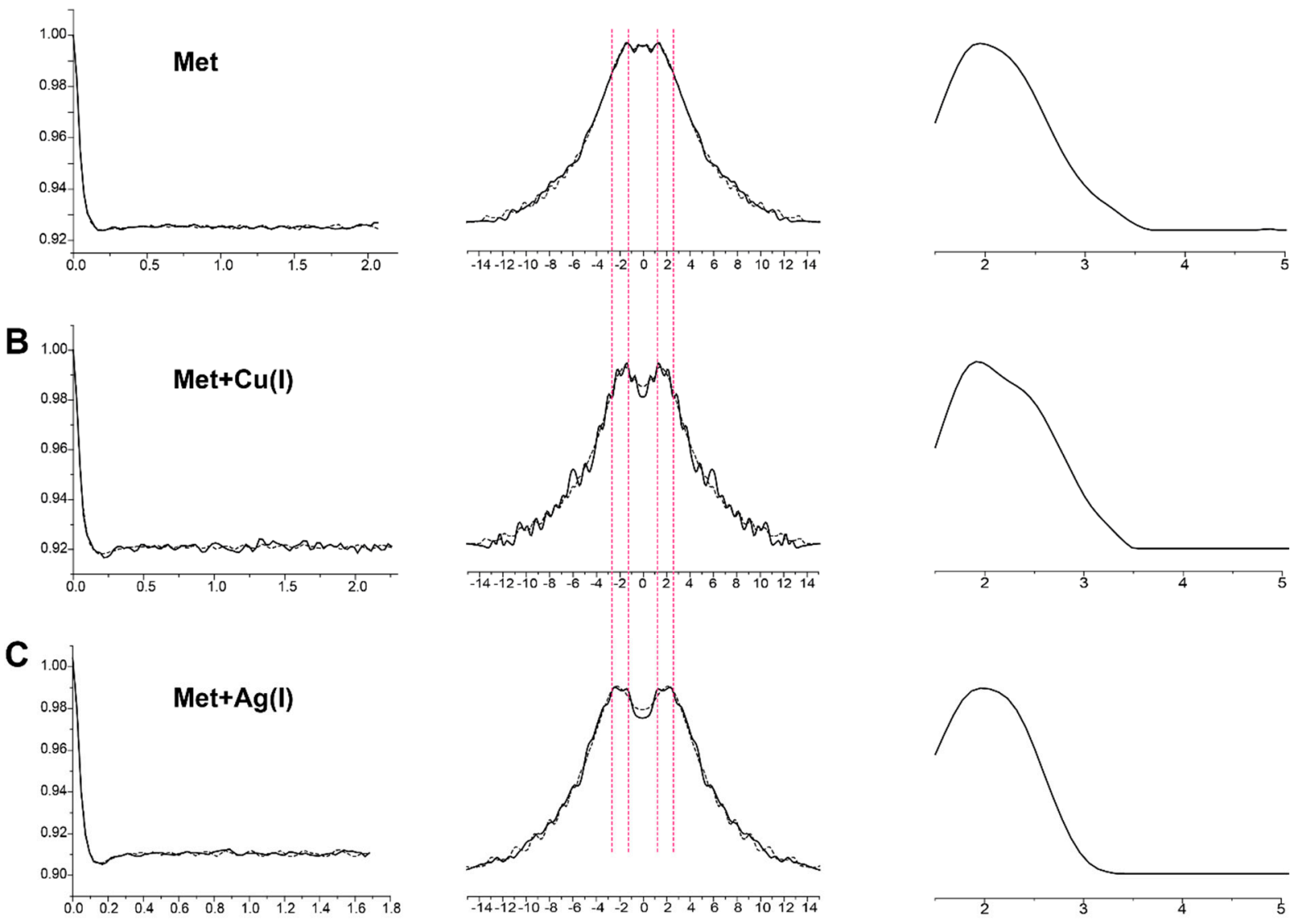

$\mathbf{T}[\mu \mathbf{s}]$

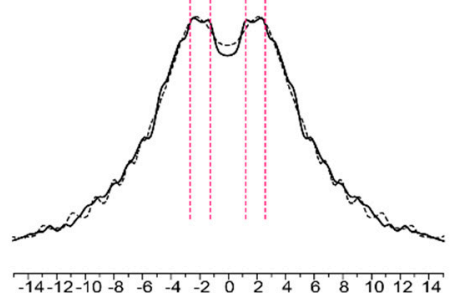

$v$ [MHz]

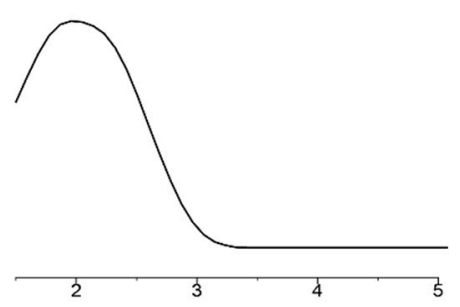

$\mathrm{r}$ [nm]

Figure 4. $\mathrm{Cu}(\mathrm{I})$ induces conformational changes in the Mets motif (Met). Q-band DEER time traces (solid lines) with simulated time traces (dotted lines), corresponding to FT spectra, and the corresponding distance distribution functions based on Tikhonov regularization for (A) Met, (B) Met $+\mathrm{Cu}(\mathrm{I})$ and $(\mathrm{C}) \mathrm{Met}+\mathrm{Ag}(\mathrm{I})$. Adapted from reference [13].

The situation differs when larger proteins are involved. In one study carried out in the laboratory, we explored the conformational changes in the full-length CusB protein [84], which is part of the CusCBA periplasmic efflux transporter in E. coli. The crystal structure of CusB was only reported in the apo-state, namely, in the absence of $\mathrm{Cu}(\mathrm{I})$ ions, with the first 88 residues missing from the structure $[85,86]$. According to the crystal structure, CusB is folded into an elongated structure ( 120 $\AA$ long and $\sim 40 \AA$ wide) comprising four domains (Figure 5A). The protein's first three domains (i.e., domains 1-3, corresponding to the membrane proximal, $\beta$-barrel, and lipoyl domains) contain mostly $\beta$-strands. The fourth domain consists of only $\alpha$-helices and is folded into a three-helix-handle structure. We found out that in solution, CusB exists as a dimer. To resolve conformational changes induced by $\mathrm{Cu}(\mathrm{I})$ (holo-state) binding, a DEER experiment was performed. However, since CusB lacks cysteine residues, we selected a set of residues in the protein where a spin-label 
could be introduced. We then individually mutated each of these residues to cysteine and spin-labeled the generated mutants with MTSSL (Figure 5A) [84]. Subsequently, the inter-monomer distance distribution was evaluated at different regions of the protein. Figure 5B shows the DEER time-domain signals for apo-CusB and holo-CusB, as well as the corresponding distance distribution functions for the various CusB mutants. It is clear that while several mutants underwent large changes in DEER distance distribution functions upon $\mathrm{Cu}(\mathrm{I})$ binding, in other mutants, these changes were minor. The most substantial changes were observed for the A248C, A236C, and S109C mutants, whereas, for N312C and G173C, only slight changes in the DEER distance distribution functions were detected. Moderate changes in the DEER signals were observed for A303C and A188C.

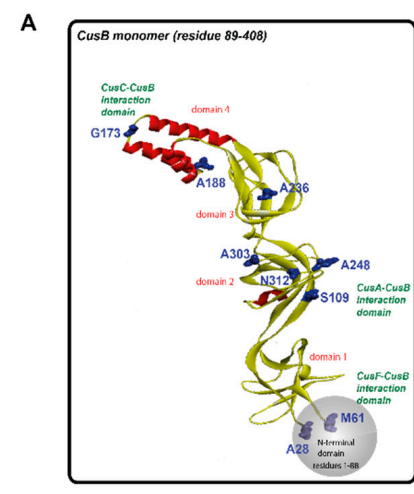

C

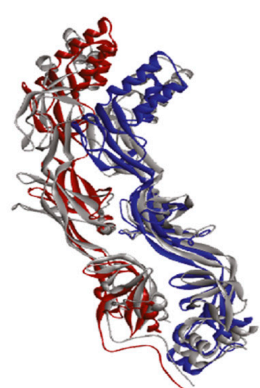

D

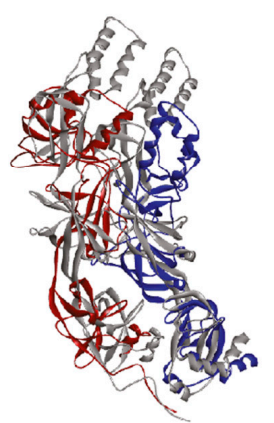

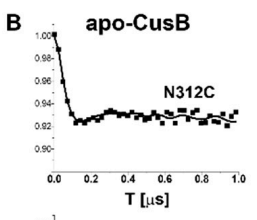
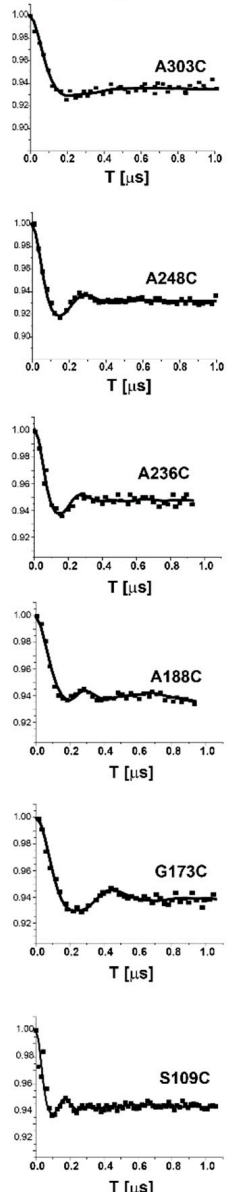
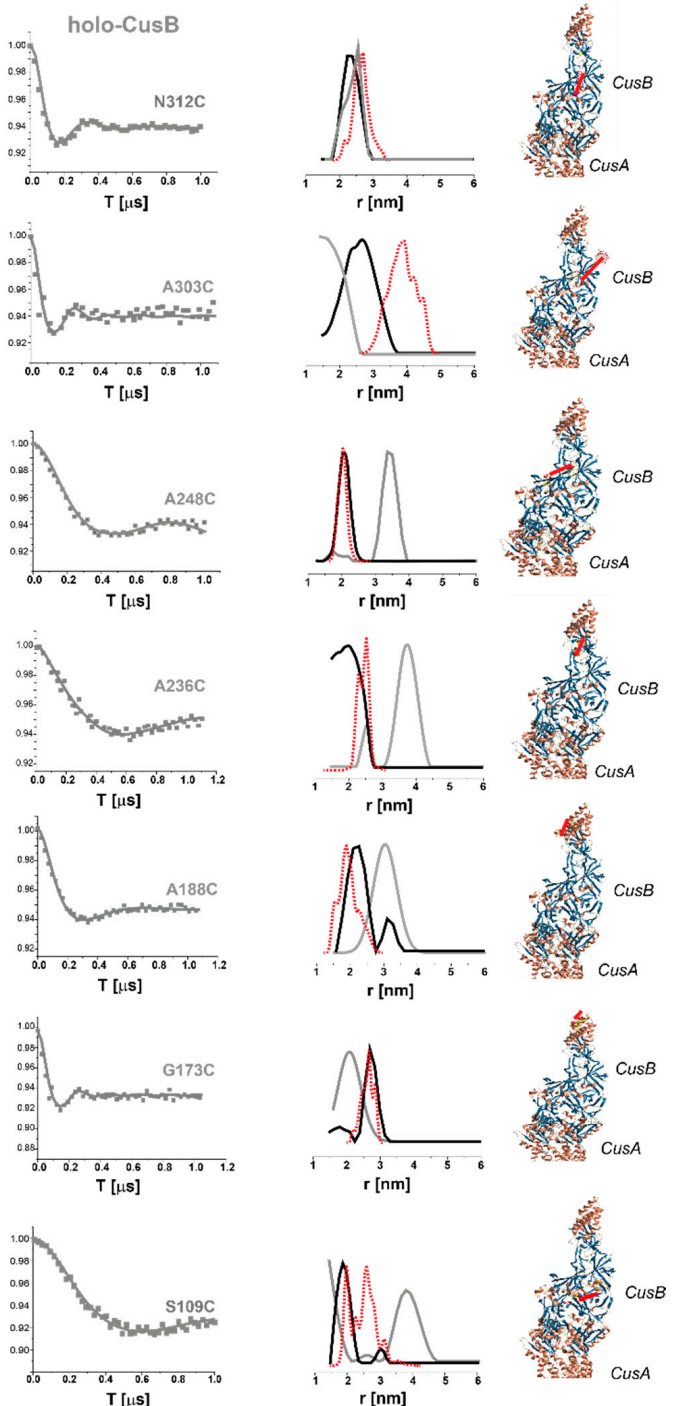

Figure 5. $\mathrm{Cu}(\mathrm{I})$ induces conformational changes in E. coli CusB. (A). A ribbon view of the CusB structure (PDB: 3H94), showing the various domains of the protein. The residue probes used in this study are denoted in blue. (B). Q-band DEER signals for various spin-labeled CusB mutants and the corresponding distance distribution functions based on Tikhonov regularization in the apo- (black line) and holo-state at a ratio of 3:1 Cu(I):CusB (gray line). The dashed red line corresponds to the distance distribution obtained from MMM. (C). A ribbon view of the CusB structure (red, molecule 1; blue, molecule 2) obtained using the ENM program for the apo-state, overlaid on the CusB crystal structure (PDB: 3NE5, gray). (D). A ribbon view of the CusB structure (solid colors) obtained using the ENM program for the holo-state, overlaid on the CusB structure in the apo-state (gray). Adapted from reference [84]. 
To compare the DEER data with the CusB crystal structure, we performed multiscale modeling of macromolecular systems (MMM software, version 2015) [87,88]. MMM is a computational approach for deriving a rotamer library based on a coarse-grained representation of the conformational space of a spin-label. This method describes spin labels as a set of alternative conformations or rotamers, which can be attached without serious clashes with the atoms of other residues or cofactors. The rotamer library is derived from molecular dynamics simulation with a total length of $100 \mathrm{~ns}$ at a temperature of $175 \mathrm{~K}$, which is an estimate of the glass transition of a protein sample. The program uses third-party software developed by the group of Dunbrack, SCWRL4 [89]. The crystal structure of CusB (PDB 3NE5) served as input to an MMM program. The dashed red line in Figure 5B denotes the distance distribution obtained from MMM. Besides A303C, the DEER distance distributions in the apo-state agree well with the crystal structure. In the next step, we explored the effect of $\mathrm{Cu}(\mathrm{I})$ on the $\mathrm{CusB}$ structure using the elastic network model (ENM) implemented in the MMM software. Inputs to the ENM are the PDB structure and the distance distribution functions obtained by DEER. Based on the DEER constraints, a suggested structure for the holo-state was purposed (Figure 5C,D). The holo-state of CusB indicted that domains 3 and 4 of $\mathrm{CusB}$ fold towards the CusCBA pore while $\mathrm{Cu}(\mathrm{I})$ binding, providing new insight into CusB function.

Conformational changes induced by metal ion binding can be observed in the DEER measurements, in comparable small soluble proteins $(<10 \mathrm{kDa})$. We succeeded in detecting such conformational changes in the small domain of the N-terminal domain of the ATP7B human transporter [90]. The N-terminal domain of ATP7B contains six metal-binding subdomains (MBDs) connected by linkers (see Figure 1A). Each MBD is about $7 \mathrm{kDa}$ and presents a ferredoxin-like fold with a compact $\beta \alpha \beta \beta \alpha \beta$ structure and a conserved metalbinding motif MXCXXC (where X stands for any amino acid) [91,92]. In one study, we explored the conformational changes induced by $\mathrm{Cu}(\mathrm{I})$ in MBD3-4 (Figure 6) [90].

A

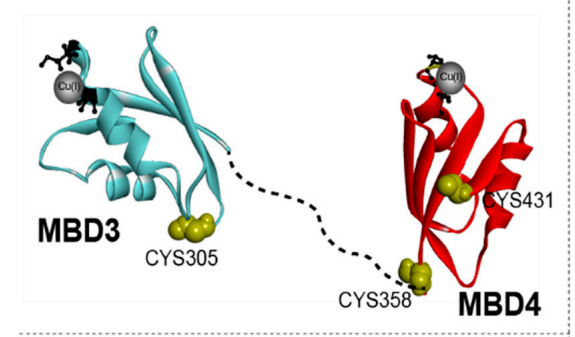

B

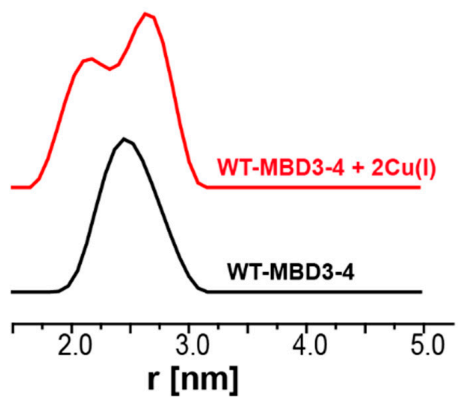

C
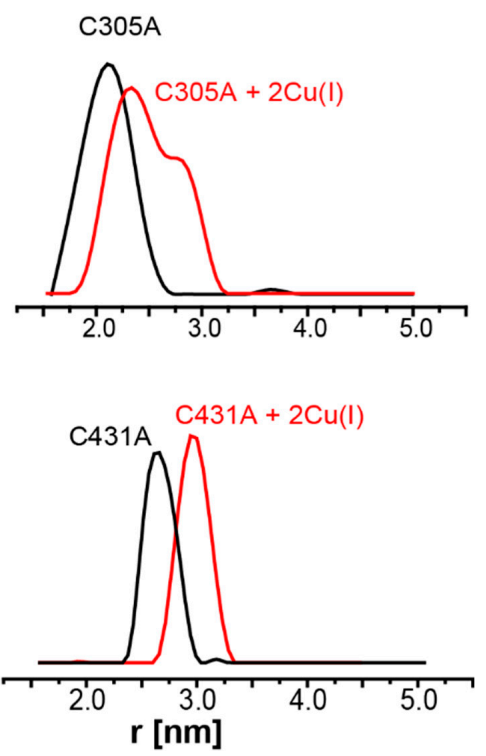

Figure 6. $\mathrm{Cu}(\mathrm{I})$ induces conformational changes in MBD3-4 of ATP7B. (A). The NMR structure of MBD3-4 (PDB: 2ROP, reference [88]) showing the three cysteine (CYS) residues accessible for spin labeling (yellow), as well as bound $\mathrm{Cu}(\mathrm{I})$ (gray). (B). The DEER distance distribution functions based on Tikhonov regularization for native (WT) MBD3-4 (spin-labeled at three different positions (C431, C358 and C305) in the absence (black line) or presence of $\mathrm{Cu}(\mathrm{I})$ (red line). (C). DEER distance distribution functions based on Tikhonov regularization for the MBD3-4_C305A mutant (corresponding to the C358R1-C431 distance), and the MBD3-4_C431A mutant (corresponding to the C305-C358 distance) in the absence (black line) or presence of $\mathrm{Cu}(\mathrm{I})$ (red line). Adapted from reference [90]. 
There are seven cysteine residues in the MBD3-4 domain [93], four of which form the two $\mathrm{Cu}(\mathrm{I})$-binding sites of the protein (one in MBD3, and the second in MBD4). Accordingly, only three cysteine residues are available for spin-labeling with MTSSL, namely, C305 (located in the loop between the MBD3 $\beta 3$ and $\alpha 2$ regions), and C358 and C431 (located in the MBD4 $\beta 1$ and $\beta 4$ stretches, respectively). Figure 6 shows the DEER distance distribution functions for native MBD3-4 and the MBD3-4_C431A and MBD3-4_C305A mutants. The latter mutations were introduced to monitor the distance distributions relative only to the two remaining cysteine residues, which were employed to detect C431-C358 and C305-C358 distance distributions in MBD4 and MBD3-4, respectively. The DEER data revealed that $\mathrm{Cu}(\mathrm{I})$ induces conformational changes in MBD3-4, specifically, that MBD3 becomes more separate from MBD4, and that the flexibility of $\beta 4$ increases upon $\mathrm{Cu}(\mathrm{I})$ binding [90].

\subsection{Following Conformational Changes in Biomolecules upon Metal Transfer}

The human copper metallochaperone Atox1 is responsible for shuttling $\mathrm{Cu}(\mathrm{I})$ ions from the hCtr1 C-terminal domains to the MBDs of ATP7A/B. Atox1 is a small soluble protein (68 amino acids) with an overall $\beta \alpha \beta \beta \alpha \beta$-fold structure. It coordinates one copper atom through the cysteine residues found in a conserved MXCXXC motif (much like the MBDs of ATP7A/B) [94,95]. The hCtr1 C-terminal domain contains 15 amino acids (SWKKAVVVDITEHCH), where the last three residues $(\mathrm{HCH})$ were suggested to comprise the last site of $\mathrm{Cu}(\mathrm{I})$ binding in hCtr1; this site is responsible for shuttling $\mathrm{Cu}(\mathrm{I})$ ions to the various $\mathrm{Cu}(\mathrm{I})$ chaperones in the cell $[96,97]$. Using DEER measurements, we investigated the interaction between Atox1 and the C-terminal domain of hCtr1 [98]. There are three cysteine residues in Atox1, with two (C12 and C15) being involved in $\mathrm{Cu}(\mathrm{I})$ coordination. As such, only Cys41 is available for spin labeling with MTSSL. Four different peptides were synthesized in order to explore the interaction between the hCtr1 C-terminal domain and Atox1, as listed in the inset table of Figure 7. Pep1 corresponds to the native segment, Pep2 is missing the last three amino acids $(\mathrm{HCH})$, whereas, in pep3 and pep4, the cysteine residue in SWKKAVVVDITEHCH (pep1) was mutated to glycine (pep3) and methionine residue (pep4), respectively. The DEER distance distribution functions measured in the absence or presence of $\mathrm{Cu}(\mathrm{I})$ are presented in Figure 7. The dipolar interaction between the spin-labels in Atox1 confirms that this protein is a dimer in solution, a conclusion that is also supported by NMR data [95,99] and cross-linking experiments [100]. DEER experiments on Atox1 revealed a bimodal distance distribution of $2.8 \pm 0.7$ and $4.5 \pm 0.4 \mathrm{~nm}$. The addition of $\mathrm{Cu}(\mathrm{I})$ somewhat narrowed the two distributions, suggesting a more packed and rigid Atox 1 structure. The distribution around $4.5 \mathrm{~nm}$ is consistent with the crystal structure conformation, while the distribution around $2.8 \mathrm{~nm}$ suggested an additional conformation of the Atox 1 that is much more flexible. To better identify the two different conformations, we performed additional DEER experiments as a function of $\mathrm{pH}$, together with efforts relying on computational methods. We assigned the distribution around $2.8 \mathrm{~nm}$ to an "open structure", a conformation in which the two C12 residues of the Atox1 dimer are involved in $\mathrm{Cu}(\mathrm{I})$ binding, and the $\mathrm{C} 15$ residues do not necessarily coordinate to $\mathrm{Cu}(\mathrm{I})$ [101]. In the "closed conformation", corresponding to the $4.5 \mathrm{~nm}$ distribution, all four cysteine residues, i.e., $\mathrm{C} 12$ and $\mathrm{C} 15$ from both monomers, coordinate to the $\mathrm{Cu}(\mathrm{I})$ ion.

The addition of the hCtr1 C-terminal domain (pep1) to the Atox1 solution yielded a bimodal distribution of $2.5 \pm 0.4$ and $4.2 \pm 0.3 \mathrm{~nm}$. The addition of $\mathrm{Cu}(\mathrm{I})$ to this solution slightly changed the population between the two distributions. It is clear, however, that the addition of pep1 to Atox1 resulted in a narrowing of the distance distribution functions, confirming the interaction between the two biomolecules, as was also confirmed by changes seen in the CW-EPR spectra [98]. DEER experiments were also performed on Atox1 in the presence of pep2, pep3, and pep4. In the presence of each of these peptides, the $\mathrm{Cu}(\mathrm{I})$ binding site was either absent or mutated. Strikingly, in the presence of these peptides, Atox 1 accommodates only one conformation, the open conformation. These results indicate that DEER experiments can follow interactions between two biomolecules that are sensitive 
to metal ion transfer between them. When one of these metal sites is lacking, there is an immediate effect on the target protein and its structure.
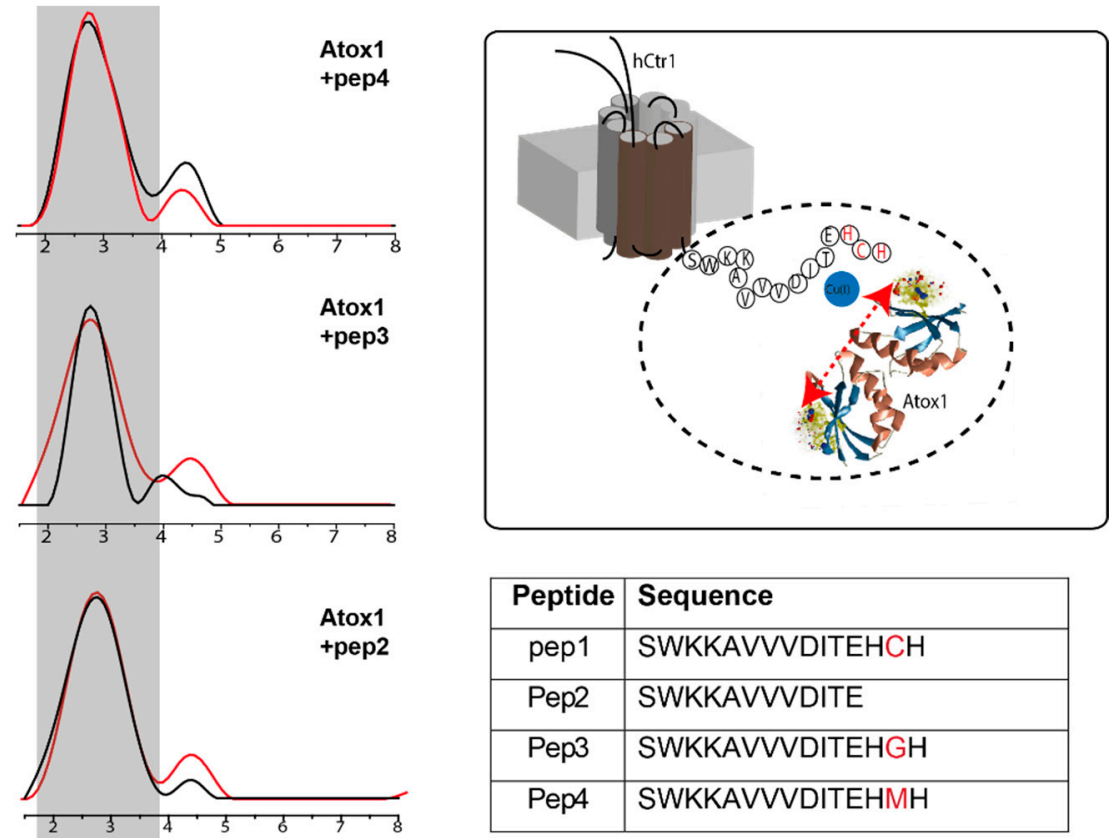

\begin{tabular}{|c|l|}
\hline Peptide & Sequence \\
\hline pep1 & SWKKAVVVDITEHCH \\
\hline Pep2 & SWKKAVVVDITE \\
\hline Pep3 & SWKKAVVVDITEHGH \\
\hline Pep4 & SWKKAVVVDITEHMH \\
\hline
\end{tabular}
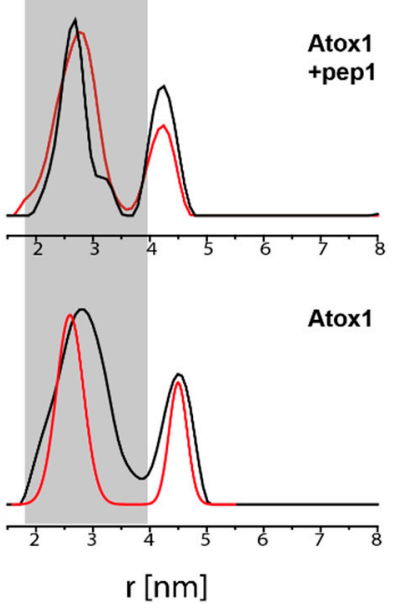

Figure 7. Following the interaction between C-terminal domain of the human copper transporter hCtr1 and the Atox1 metallochaperone. Q-band distance distribution functions based on Tikhonov regularization in the absence (black solid lines) or presence of $\mathrm{Cu}(\mathrm{I})$ (red solid lines). The gray area marks the distribution around $2.5 \mathrm{~nm}$. The $\mathrm{Cu}(\mathrm{I})$ - binding site in the C-terminal domain of hCtr1 $(\mathrm{HCH})$ was mutated to generate different sequences, as listed in the inset table. Adapted from ref [98] with permission.

Using DEER measurements, we also explored transient interactions that occur between Atox1 and MBD3-4 [90,102]. Interestingly, adding spin-labeled Atox1 to spin-labeled MBD34 solution led to the disappearance of the distribution around $4.2 \mathrm{~nm}$, suggesting that Atox1 no longer exists as a homodimer, as confirmed by cross-linking experiments [90]. Moreover, the additional peak appearing at $3.4 \pm 0.3 \mathrm{~nm}$ (the gray area in Figure 8 ) can be assigned to the formation of an MBD3-4-Atox1 complex (corresponding to the distance between C41 of Atox1 and C431/C358/C305 of MBD3-4). In the presence of $\mathrm{Cu}(\mathrm{I})$, the distributions are narrower, suggesting the formation of a less dynamic and more rigid complex. The DEER experiments on MBD3-4_C305A, where only MBD4 is spin-labeled, presented results very similar to those obtained with native MBD3-4, suggesting that Atox1 mostly interacts with MBD4, and less so with MBD3 (Figure 8B), which was also confirmed 
by MD simulations [90]. This was later supported by EPR experiments performed on MBD13 and MBD4-6 [102]. These experiments showed the sensitivity of EPR to the interaction between two biomolecules as a function of metal ion binding.

A

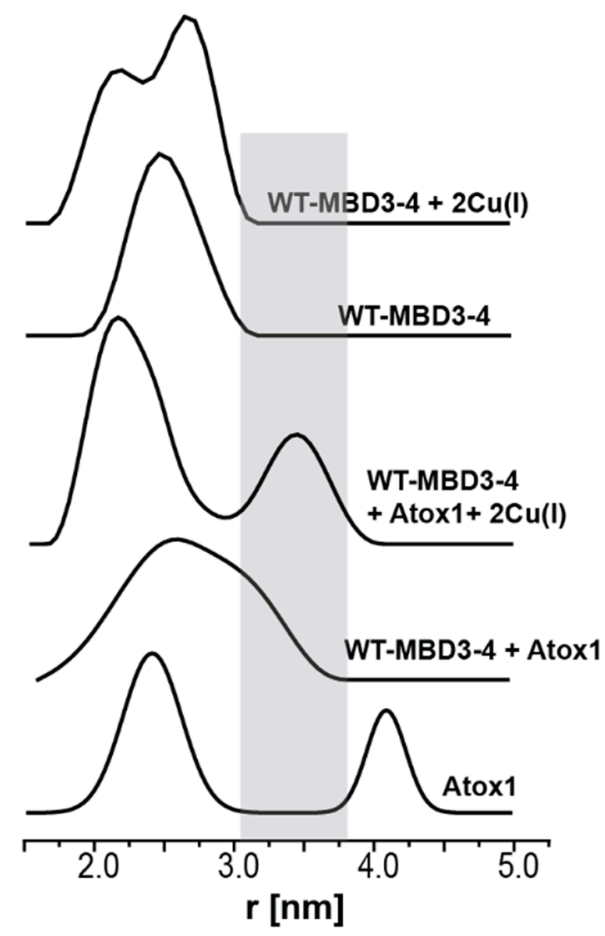

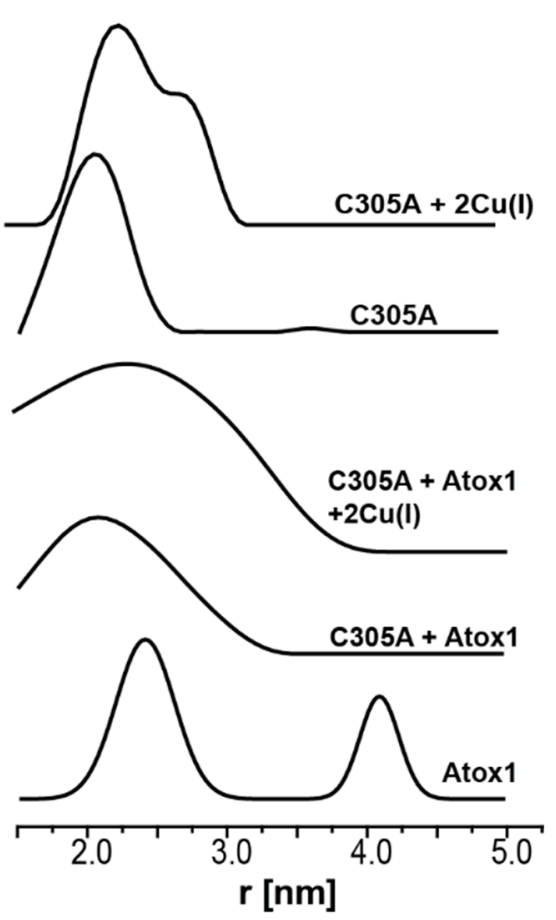

$\mathbf{r}[\mathrm{nm}]$

B

face-to-face model

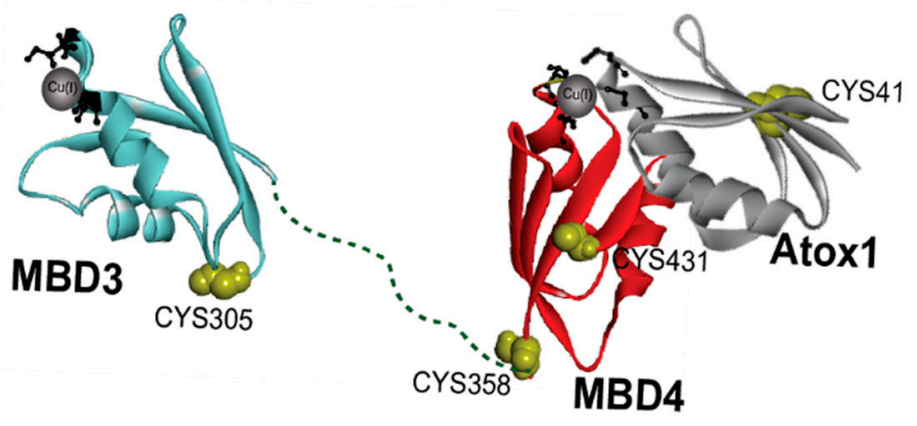

Figure 8. Following the interaction between MBD3-4 of ATP7B and the Atox1 metallochaperone. (A). Q-band distance distribution functions using Tikhonov regularization of spin-labeled (WT) MBD3-4 and the MBD3-4_C305A mutant in the presence and absence of spin-labeled Atox1 and $\mathrm{Cu}(\mathrm{I})$. The gray area marks the distance distribution raised owing to the interaction between Atox1 and MBD4. (B). A structural model for the interaction between MBD3-4 and Atox1. Adapted from reference [90].

\subsection{Identifying Metal Coordination Sites}

In the previous section, we showed how DEER could resolve structural changes that occur in $E$. coli $\mathrm{CusB}$ as a function of its interaction with $\mathrm{Cu}(\mathrm{I})$. The crystal structure of holoCusB has yet to be solved, leaving numerous open questions regarding its mechanism of action. One question refers to the number of $\mathrm{Cu}(\mathrm{I})$-binding sites that are in $\mathrm{CusB}$. Although CusB lacks cysteine residues, it contains ten methionine residues that can play a role in $\mathrm{Cu}(\mathrm{I})$ coordination. We hypothesized that deletion of a single methionine residue in CusB would affect cell viability upon copper stress. Therefore, we generated cells transformed to express CusB in which one of these methionines was mutated to isoleucine. When cell 
growth under copper stress conditions was addressed, it was observed that of the ten methionine residues in the protein, replacing four of them (M64, M227, M241 and M398) affected cell viability and growth much more than did the replacement of the other six [103]. Based on these findings, we then expressed and purified various CusB mutants for DEER analysis. More specifically, we introduced cysteine residues for MTSSL labeling in domains 2 and 3 at A236C and A248C, respectively, positions which were previously shown to undergo major changes upon $\mathrm{Cu}(\mathrm{I})$ binding (Figure 5). Additionally, we replaced each time one of the following methionine residues (M64I, M227I, M241I, and M398I) [103]. The DEER data from the analysis are presented in Figure 9.

A

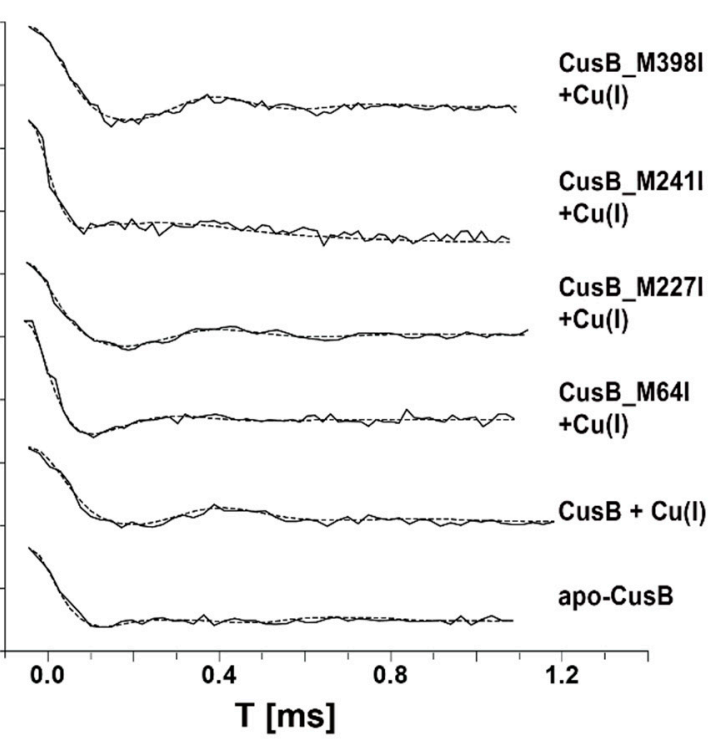

B

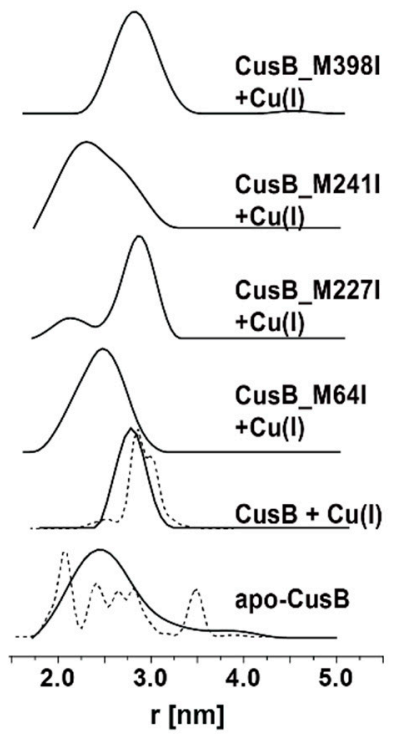

C

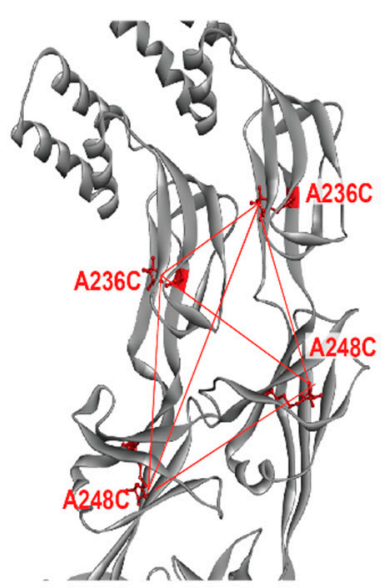

Figure 9. Distance distribution measurements (DEER) on CusB mutants. (A). DEER time domain signals (solid lines) and fits (dashed lines) based on Tikhonov regularization for apo-CusB and CusB $+\mathrm{Cu}(\mathrm{I})($ at a $\mathrm{Cu}(\mathrm{I}): \mathrm{CusB}$ ratio of 3:1) and various $\mathrm{CusB}+\mathrm{Cu}(\mathrm{I})$ mutants spin-labeled at the A236C and $\mathrm{A} 248 \mathrm{C}$ positions. (B). Corresponding distance distribution functions. The dashed lines represent calculated distribution functions obtained for the apo-CusB and $\mathrm{CusB}+\mathrm{Cu}(\mathrm{I})$ structure models. (C). The positions of the spin labels in WT-CusB (A236C, A248C). The red dotted lines denote the six distances targeted here under the broad distance distribution. Adapted from reference [103].

The distance distribution consists of all distances derived from the four spin-labels attached to the CusB dimer. For CusB mutated only in A236C and A248C for spin labeling, distance distributions of $2.5 \pm 0.5 \mathrm{~nm}$ for the apo-state and $2.8 \pm 0.3 \mathrm{~nm}$ for the holo-state (in the presence of $\mathrm{Cu}(\mathrm{I})$ ) were detected. Since it is a four-spin system, ghost distributions may exist. Hence, we also used the ghost suppression method for a multi-spin system (implemented in the DeerAnalysis program) [104]. MMM software was then used to compare these distances with the structures obtained from the DEER experiments in Figure 5. The dashed lines in Figure 9B show that the distributions obtained are consistent with what was expected. The DEER data also confirmed that when M64, M227 or M241 was mutated, structural changes in CusB associated with $\mathrm{Cu}(\mathrm{I})$ binding were affected; no structural effect was detected for the M398I mutant. For simplicity, we used a linear composition of the apo-CusB distance distribution with the holo-CusB distance distribution.

For CusB_M398I, the best fit was obtained with the 100\% holo-state, for CusB_M227I, with $50 \%$ of the holo-state, for M241I, with $10 \%$ of the holo-state, while for CusB_M64I, the best fit was obtained with $0 \%$ of the holo-state. This indicates that the most important methionine residues for $\mathrm{Cu}(\mathrm{I})$ coordination can be ranked in the following order: M64 > M241 > M227 > M398. These results were also confirmed by microscopy experi- 
ments, as well as by UV-Vis experiments. Microscopy experiments showed that the viability of the cell, when exposed to copper, was lowest when the M64I mutation was introduced in CusB, and that no effect was seen in the M398I mutant. UV-Vis confirmed that the affinity of $\mathrm{Cu}(\mathrm{I})$ to $\mathrm{CusB}$ was lowest with the M64I mutant.

Mutagenesis and EPR were used to explore the role of Cys12 and Cys15 in $\mathrm{Cu}(\mathrm{I})$ binding by the Atox1 metallochaperone [101]. To determine the importance of these residues to $\mathrm{Cu}(\mathrm{I})$ binding, we introduced $\mathrm{C} 12 \mathrm{~A}, \mathrm{C} 12 \mathrm{M}$ and $\mathrm{C} 15 \mathrm{~A}$, and $\mathrm{C} 15 \mathrm{M}$ mutations. The CW-EPR spectra of the apo- and holo-forms of Atox1_C15A are characterized by an increase in dynamics, as compared to the native protein, and disappearance of the dipolar interaction (Figure 10). This suggests that in the presence of C15A, Atox1 is in the monomeric state. Indeed, the DEER signal of apo-C15A did not show any dipolar modulation, demonstrating that Atox 1 is in a monomeric state when the C15A mutation is present. In addition, in the presence of $\mathrm{Cu}(\mathrm{I})$, a reduction in the signal-to-noise ratio was observed, suggesting aggregation of the protein, and instability in the presence of the $\mathrm{C} 15 \mathrm{~A}$ mutation and $\mathrm{Cu}(\mathrm{I})$. In the presence of the $\mathrm{C} 15 \mathrm{M}$ mutation, the protein is a bit more stable and is also partially found in the dimeric state in the presence of $\mathrm{Cu}(\mathrm{I})$ ion (i.e., the holo-state), suggesting that this mutation partially retrieves the functionality of Atox1. The C12A and C12M mutations did not affect dimerization of Atox1, although instability of the protein was greatly increased in the presence of $\mathrm{Cu}(\mathrm{I})$, with aggregates appearing. In conclusion, the CW-EPR experiments suggest that the Cys 15 residue is important for Atox1 dimerization, while Cys12 is important for protein stability in the presence of $\mathrm{Cu}(\mathrm{I})$, suggesting that $\mathrm{Cys} 12$ is critical for $\mathrm{Cu}(\mathrm{I})$ binding. Multi-scale MD simulations were carried out to confirm this [101]. These simulations also identified Cys12 as a critical residue for $\mathrm{Cu}(\mathrm{I})$ binding, while coordination of $\mathrm{Cu}(\mathrm{I})$ with $\mathrm{Cys} 15$ could be exchanged. The coordination of $\mathrm{Cu}(\mathrm{I})$ to $\mathrm{Cys} 15$ controlled the conformational changes between the open and closed states of Atox1.
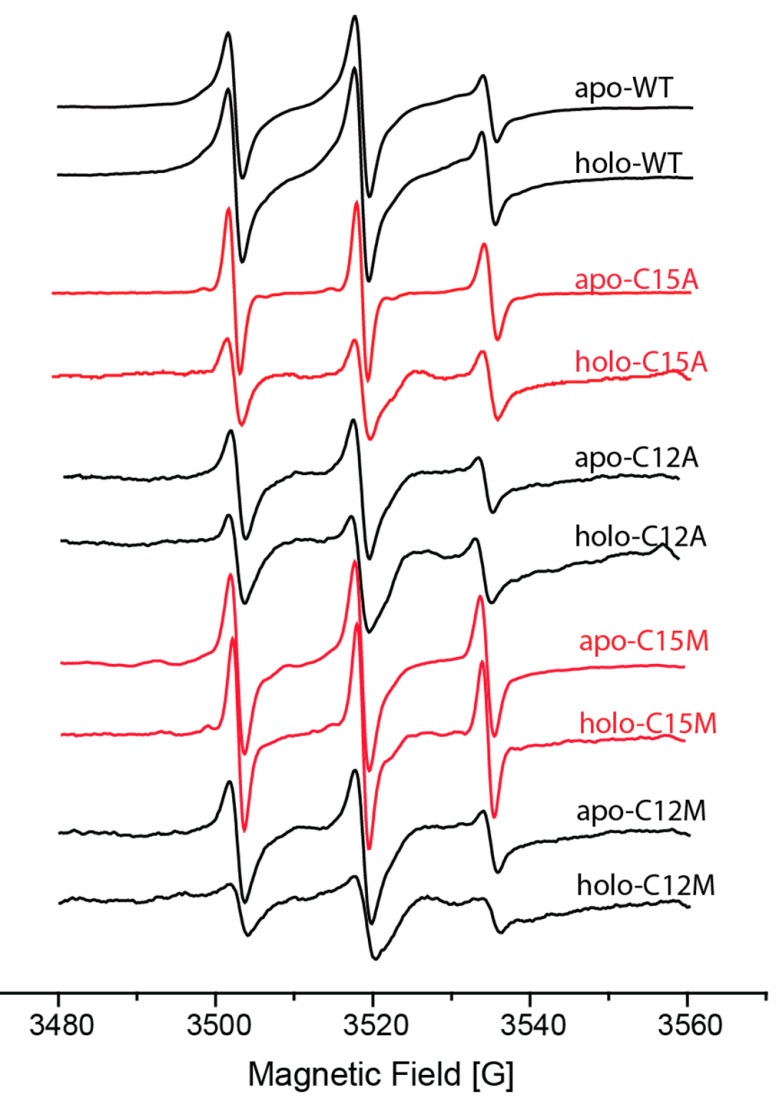

Figure 10. Effect of cysteine mutagenesis on $\mathrm{Cu}(\mathrm{I})$ binding to Atox1. RT CW-EPR spectra of various Atox1 mutants in the presence or absence of $\mathrm{Cu}(\mathrm{I})$. Adapted from reference [101]. 


\section{Conclusions}

Here, we showed that EPR spectroscopy can follow a cellular process that involves small ligand transfer at the structural level. While NMR and X-ray crystallography can resolve the complete 3D structure of a metal-binding protein, including the metal-binding site, these techniques are limited by protein size and by its ability to crystalize. Likewise, EXAFS can provide information on the metal-binding site but not on conformational changes induced in the protein upon metal binding. Fluorescence resonance energy transfer (FRET) can provide useful information on the kinetics of the mechanism of metal transfer between proteins yet offers less insight at the structural level. In this contribution, we provided examples of the advantages of using EPR spectroscopy for such efforts, as EPR spectroscopy is not limited by protein size. As such, the formation of complexes upon metal ion binding can be monitored by this approach. EPR spectroscopy can follow conformational changes in small and large proteins, as well as in highly dynamics proteins, upon metal ion binding. EPR spectroscopy is also sensitive to the properties and characteristics of the metal ions, with different metal ions inducing different conformational changes. In addition, minor conformational changes can be targeted in two proteins when a metal ion is transferred, providing important information on the mechanism of metal ion transfer. Finally, by combining EPR spectroscopy and mutagenesis, metal-binding sites can be characterized.

In other studies, which were not discussed here, diamagnetic metal sites have been resolved by EPR spectroscopy by replacing the diamagnetic metal ions with a similar paramagnetic metal ion. For example, by replacing $\mathrm{Mg}$ (II) or $\mathrm{Zn}$ (II) with $\mathrm{Mn}$ (II) or $\mathrm{Cu}(\mathrm{II})[105,106]$, which possess similar properties, and, in most cases, they bind to the biomolecule similarly to the diamagnetic metal ion.

At the same time, EPR spectroscopy cannot provide a full 3D structure of the protein or protein complexes being studied without the use of modeling and computational methods. In addition, the most used spin-label, MTSSL, is highly flexible, which leads to broad distance distributions. The use of other spin-labels, such as dHis-Cu(II), can lead to much narrower distance distribution $[17,107]$, and can overcome the limitations associated with the use of MTSSL. dHis-Cu(II) spin-labeling has recently been shown to hold high affinity and stability against competitor metal ions (even in an acidic environment) to biomolecules. In this study, a nanomolar concentration of the protein was studied by EPR spectroscopy, which is also applicable for in-vivo research $[80,108]$. In addition, the combination of several techniques, such as microscopy [103,109], copper uptake experiments using ${ }^{64} \mathrm{Cu}[110]$, UV-Vis and NMR [13,111], can provide a better and more complete picture on Cu-related biological processes.

Author Contributions: S.M., Y.S. and S.R. writing-review and editing. All authors have read and agreed to the published version of the manuscript.

Funding: This research was funded by an ERC-STG grant No. 754365 awarded to S.R. The illustrations in Figure 1 were created using Biorender.

Institutional Review Board Statement: Not applicable.

Informed Consent Statement: Not applicable.

Conflicts of Interest: The authors declare no conflict of interest.

\section{References}

1. Kosman, D.J. The teleos of metallo-reduction and metallo-oxidation in eukaryotic iron and copper trafficking. Metallomics 2018, 10, 370-377. [CrossRef] [PubMed]

2. Burkhead, J.L.; Gogolin Reynolds, K.A.; Abdel-Ghany, S.E.; Cohu, C.M.; Pilon, M. Copper Homeostasis. New Phytol. 2009, 182, 799-816. [CrossRef] [PubMed]

3. Krabbe, J.; Esser, A.; Kanzler, S.; Braunschweig, T.; Kintsler, S.; Spillner, J.; Schroder, T.; Kalverkamp, S.; Balakirski, G.; Gerhards, B.; et al. The effects of zinc- and copper-containing welding fumes on murine, rat and human precision-cut lung slices. J. Trace Elem. Med. Biol. 2018, 49, 192-201. [CrossRef] [PubMed]

4. Madsen, E.; Gitlin, J.D. Copper and Iron Disorders of the Brain. Annu. Rev. Neurosci. 2007, 30, 317-337. [CrossRef] 
5. Dalecki, A.G.; Crawford, C.L.; Wolschendorf, F. Copper and Antibiotics: Discovery, Modes of Action, and Opportunities for Medicinal Applications. Adv. Microb. Physiol. 2017, 70, 193-260. [CrossRef]

6. Denoyer, D.; Masaldan, S.; La Fontaine, S.; Cater, M.A. Targeting copper in cancer therapy: 'Copper That Cancer'. Metallomics 2015, 7, 1459-1476. [CrossRef]

7. Dollwet, H.; Sorenson, J.R.J. Historic uses of copper compunds in medicine. Trace Elem. Med. 1985, 2, 80-87.

8. Donnelly, P.S.; Xiao, Z.; Wedd, A.G. Copper and Alzheimer's disease. Curr. Opin. Chem. Biol. 2007, 11, 128-133. [CrossRef]

9. Innocenti, M.; Salvietti, E.; Guidotti, M.; Casini, A.; Bellandi, S.; Foresti, M.L.; Gabbiani, C.; Pozzi, A.; Zatta, P.; Messori, L. Trace copper(II) or zinc(II) ions drastically modify the aggregation behavior of amyloid-beta1-42: An AFM study. J. Alzheimers Dis. 2010, 19, 1323-1329. [CrossRef]

10. Hofmann, L.; Hirsch, M.; Ruthstein, S. Advances in Understanding of the Copper Homeostasis in Pseudomonas aeruginosa. Int. J. Mol. Sci. 2021, 22, 2050. [CrossRef]

11. Magistrato, A.; Pavlin, M.; Qasem, Z.; Ruthstein, S. Copper trafficking in eukaryotic systems: Current knowledge from experimental and computational efforts. Curr. Opin. Struct. Biol. 2019, 58, 26-33. [CrossRef]

12. Banci, L.; Bertini, I.; Ciofi-Baffoni, S. Copper trafficking in biology: An NMR approach. HFSP J. 2009, 3, 165-175. [CrossRef]

13. Shenberger, Y.; Gottlieb, H.E.; Ruthstein, S. EPR, NMR, and CD spectroscopy provide inputs on the coordination of $\mathrm{Cu}(\mathrm{I})$ and $\mathrm{Ag}(\mathrm{I})$ to a disordered methionine segment. J. Biol. Inorg. Chem. 2014, 20, 719-727. [CrossRef]

14. Gui, Z.; Green, A.R.; Kasrai, M.; Bancroft, G.M.; Stillman, M.J. Sulfur K-Edge EXAFS Studies of Cadmium-, Zinc-, Copper-, and Silver-Rabbit Liver Metallothioneins. Inorg. Chem. 1996, 35, 6520-6529. [CrossRef]

15. McDonald, A.; Pushie, M.J.; Millhauser, G.L.; George, G.N. New insights into metal interactions with the prion protein: EXAFS analysis and structure calculations of copper binding to a single octarepeat from the prion protein. J. Phys. Chem. B 2013, 117, 13822-13841. [CrossRef] [PubMed]

16. Rusanova, D.; Pike, K.J.; Persson, I.; Hanna, J.V.; Dupree, R.; Forsling, W.; Antzutkin, O.N. Solid-state NMR and EXAFS spectroscopic characterization of polycrystalline copper(I) $\mathrm{O}, \mathrm{O}^{\prime}$-dialkyldithiophosphate cluster compounds: Formation of copper(I) O,O'-diisobutyldithiophosphate compounds on the surface of synthetic chalcocite. Chemistry 2006, 12, 5282-5292. [CrossRef]

17. Sameach, H.; Ghosh, S.; Gevorkyan-Airapetov, L.; Saxena, S.; Ruthstein, S. EPR Spectroscopy Detects Various Active State Conformations of the Transcriptional Regulator CueR. Angew. Chem. Int. Ed. Engl. 2018, 58, 3053-3056. [CrossRef]

18. Tottey, S.; Harvie, D.R.; Robinson, N.J. Understanding how cells allocate metals using metal sensors and metallochaperone. Acc. Chem. Res. 2005, 38, 775-783. [CrossRef]

19. Eisses, J.F.; Kaplan, J.H. Molecular Characterization of hCTR1, the Human Copper Uptake Protein. J. Biol. Chem. 2002, 277, 29162-29171. [CrossRef] [PubMed]

20. Lee, J.; Pena, M.M.O.; Nose, Y.; Thiele, D.J. Biochemical Characterization of the Human Copper Transporter Ctr1. J. Biol. Chem. 2002, 277, 4380-4387. [CrossRef] [PubMed]

21. Puig, S.; Thiele, D.J. Molecular mechanisms of copper uptake and distribution. Curr. Opin. Chem. Biol. 2002, 6, 171-180. [CrossRef]

22. Robinson, N.J.; Winge, D.R. Copper Metallochaperones. Annu. Rev. Biochem. 2010, 79, 537-562. [CrossRef]

23. Rosenzweig, A.C. Copper delivery by metallochaperone proteins. Acc. Chem. Res. 2001, 34, 119-128. [CrossRef]

24. Arnesano, F.; Banci, L.; Bertini, I.; Huffman, D.L.; O'Halloran, T.V. Solution strcuture of the Cu(I) and Apo forms of the yeast metallochaperone, Atx1. Biochemistry 2001, 40, 1528-1539. [CrossRef]

25. Wernimont, A.M.; Huffman, D.L.; Lamb, A.L.; O'Halloran, T.V.; Rosenzweig, A.C. Structural basis for copper transfer by the metallochaperone for the Menkes/Wilson disease proetin. Nat. Struct. Biol. 2000, 7, 766-771. [PubMed]

26. Nevitt, T.; Ohrvik, H.; Thiele, D.J. Charting the travels of copper in eukaryotes from yeast to mammals. Biochem. Biophys. Acta 2012, 1823, 1580-1593. [CrossRef] [PubMed]

27. Ward, S.K.; Abomoelak, B.; Hoye, E.A.; Steinberg, H.; Talaat, A.M. CtpV: A putative copper exporter required for full virulence of Mycobacterium tuberculosis. Mol. Microbiol. 2010, 77, 1096-1110. [CrossRef] [PubMed]

28. Su, C.-C.; Long, F.; Yu, E.W. The Cus efflux system removes toxic ions via a methionine shuttle. Protein Sci. 2011, $20,6-18$. [CrossRef] [PubMed]

29. Chacón, K.N.; Mealman, T.D.; McEvoy, M.M.; Blackburn, M.E. Tracking metal ions through a Cu/Ag efflux pump assigns the functional roles of the periplasmic proteins. Proc. Nat. Acad. Sci. USA 2014, 111, 15373-15378. [CrossRef]

30. Roberts, S.A.; Weichsel, A.; Grass, G.; Thakali, K.; Hazzard, J.T.; Tollin, G.; Rensing, C.; Montfort, W.R. Crystal structure and electron transfer kinetics of $\mathrm{CueO}$, a multicopper oxicdase required for copper homeostasis in Escherichia coli. Proc. Nat. Acad. Sci. USA 2002, 99, 2766-2771. [CrossRef]

31. Rowland, J.L.; Niederweis, M. Resistance mechanisms of Mycobacterium tuberculosis against phagosomal copper overload. Tuberculosis 2012, 92, 202-210. [CrossRef] [PubMed]

32. Brown, N.L.; Stoyanov, J.V.; Kidd, S.P.; Hobman, J.L. The MerR family of transcriptional regulators. FEMS Microbiol. Rev. 2003, 27, 145-163. [CrossRef]

33. Wladron, K.J.; Rutherford, J.C.; Ford, D.; Robinson, N.J. Metalloproteins and metal sensing. Nature 2009, 460, 823-830. [CrossRef]

34. Hitomi, Y.; Outten, C.E.; O'Halloran, T.V. Extreme Zinc-binding thermodynamics of the metal sensor/regulator protein, ZntR. J. Am. Chem. Soc. 2001, 123, 8614-8615. [CrossRef] 
35. Outten, C.E.; Outten, F.W.; O'Halloran, T.V. DNA distortion mechanism for transcriptional activation by ZntR, a Zn(II)-responsive MerR homologue in Escherichia coli. J. Biol. Chem. 1999, 274, 37517-37524. [CrossRef] [PubMed]

36. Changela, A.; Chen, K.; Holschen, J.; Outten, C.E.; O'Halloran, T.V.; Mondragon, A. Molecular basis of metal-ion selectivity and zeptomolar sensitivity by CueR. Science 2003, 301, 1383-1387. [CrossRef] [PubMed]

37. Outten, F.W.; Outten, C.E.; Hale, J.A.; O'Halloran, T.V. Transcriptional activation of an Escherichia coli copper efflux regulon by the chromosomal Mer homologue, CueR. J. Biol. Chem. 2000, 275, 31024-31029. [CrossRef]

38. Chen, K.; Yuldasheva, J.E.; Penner-Hahn, J.E.; O'Halloran, T.V. An Atypical Linear Cu(I)-S2 Center Constitutes the High-Affinity Metal-Sensing Site in the CueR Metalloregulatory Protein. J. Am. Chem. Soc. 2003, 125, 12088-12089. [CrossRef]

39. Stoyanov, J.V.; Hobman, J.L.; Brown, N.L. CueR (YbbI) of Escherichia coli is a MerR family regulator controlling expression of the copper exporter CopA. Mol. Microbiol. 2001, 39, 502-512. [CrossRef]

40. Schultz, L.W.; Chivers, P.T.; Raines, R.T. The CXXC motif: Crystal structure of an active-site variant of Escherichia coli thioredoxin Acta Cryst. D Biol Cryst. 1999, 55, 1533-1538. [CrossRef]

41. Voskoboinik, I.; Strausak, D.; Greenough, M.; Brooks, H.; Petris, M.; Smith, S.; Mercer, J.F.; Camakaris, J. Functional analysis of the N-terminal CXXC metal-binding motifs in the human Menkes copper-transporting P-type ATPase expressed in cultured mammalian cells. J. Biol. Chem. 1999, 274, 22008-22012. [CrossRef]

42. Pushie, M.J.; Shaw, K.; Franz, K.J.; Shearer, J.; Haas, K.L. Model Peptide Studies Reveal a Mixed Histidine-Methionine Cu(I) Binding Site at the N-Terminus of Human Copper Transporter 1. Inorg Chem. 2015, 54, 8544-8551. [CrossRef]

43. Xue, Y.; Davis, A.V.; Balakrishnan, G.; Stasser, J.P.; Staehlin, B.M.; Focia, P.; Spiro, T.G.; Penner-Hahn, J.E.; O’Halloran, T.V. Cu(I) recognition via cation-pi and methionine interactions in CusF. Nat. Chem. Biol. 2008, 4, 107-109. [CrossRef]

44. Rubino, J.T.; Riggs-Gelasco, P.; Franz, K.J. Methionine motifs of copper transport proteins provide general and flexible thioetheronly binding sites for $\mathrm{Cu}(\mathrm{I})$ and $\mathrm{Ag}(\mathrm{I})$. J. Biol. Inorg. Chem. 2010, 15, 1033-1049. [CrossRef] [PubMed]

45. Banham, J.E.; Baker, C.M.; Ceola, S.; Day, I.J.; Grant, G.H.; Groenen, E.J.J.; Rodgers, C.T.; Jeschke, G.; Timmel, C.R. Distance measurements in the borderline region of applicability of CW EPR and DEER: A model study on a homologous series of spin-labelled peptides. J. Magn. Reason. 2008, 191, 202-218. [CrossRef] [PubMed]

46. Banham, J.E.; Jeschke, G.; Timmel, C.R. Evidence from EPR that nitroxide spin labels attached to human hemoglobin alter their conformation upon freezing. Mol. Phys. 2007, 105, 2041-2047. [CrossRef]

47. Bennati, M.; Robblee, J.H.; Mugnaini, V.; Stubbe, J.; Freed, J.H.; Borbat, P. EPR distance measurements support a model for long-range radical initiation in E. coli ribonucleotide reductase. J. Am. Chem. Soc. 2005, 127, 15014-15015. [CrossRef] [PubMed]

48. Borbat, P.P.; Surendhran, K.; Bortolus, M.; Zou, P.; Freed, J.H.; Mchaourab, H.S. Conformational motion of the ABC transporter MsbA induced by ATP hydrolysis. PLoS Biol. 2007, 5, 2211-2219. [CrossRef] [PubMed]

49. Hemminga, M.A.; Berliner, L.J. ESR Spectroscopy in Membrane Biophysics; Springer Science+Business Media, LLC: New York, NY, USA, 2007; Volume 27.

50. Hilger, D.; Jung, H.; Padan, E.; Wegener, C.; Vogel, K.P.; Steinhoff, H.J.; Jeschke, G. Assessing oligomerization of membrane proteins by four-pulse DEER: $\mathrm{pH}$-dependent dimerization of $\mathrm{NhaA} \mathrm{Na}{ }^{+} / \mathrm{H}^{+}$antiporter of E. coli. Biophys. J. 2005, 89, 1328-1338. [CrossRef]

51. Jeschke, G.; Polyhach, Y. Distance measurements on spin-labelled biomacromolecules by pulsed electron paramagnetic resonance Phys. Chem. Chem. Phys. 2007, 9, 1895-1910. [CrossRef] [PubMed]

52. Raitsimring, A.M.; Gunanathan, C.; Potapov, A.; Efremenko, I.; Martin, J.M.L.; Milstein, D.; Goldfarb, D. Gd ${ }^{3+}$ complexes as potential spin labels for high field pulsed EPR distance measurements. J. Am. Chem. Soc. 2007, 129, 14138-14139. [CrossRef]

53. Sicoli, G.; Mathis, G.; Delalande, O.; Boulard, Y.; Gasparutto, D.; Garnbarelli, S. Double electron-electron resonance (DEER): A convenient method to probe DNA conformational changes. Angew. Chem. Int. Ed. 2008, 47, 735-737. [CrossRef]

54. Xu, Q.; Ellena, J.F.; Kim, M.; Cafiso, D.S. Substrate-Dependent unfolding of the energy coupling motif of a membrane transport protein determined by double electron-electron resonance. Biochemistry 2006, 45, 10847-10854. [CrossRef]

55. Sahu, I.D.; Kroncke, B.M.; Zhang, R.; Dunagan, M.M.; Smith, H.J.; Craig, A.; McCarrick, R.M.; Sanders, C.R.; Lorigan, G.A Structural Investigation of the Transmembrane Domain of KCNE1 in Proteoliposomes. Biochemistry 2014, 53, 6391-6401. [CrossRef] [PubMed]

56. Atherton, N.M. Principles of Electron. Spin Resonance; Ellis Horwood PTR Prentice Hall: Hemel Hempstead, UK, 1993.

57. Weil, J.A.; Bolton, J.R. Electron. Paramagnetic Resonance; John Wiley and Sons Inc.: Hoboken, NJ, USA, 2007.

58. Schweiger, A.; Jeschke, G. Principles of Electron. Paramgnetic Resonance; University Press: Oxford, UK, 2001.

59. Hubbell, W.L.; Gross, A.; Langen, R.; Lietzow, M.A. Recent advances in site-directed spin labeling of proteins. Curr. Opin. Struct. Biol. 1998, 8, 649-656. [CrossRef]

60. Columbus, L.; Hubbell, W.L. A new spin on protein dynamics. Trends Biochem. Sci. 2002, 27, 288-295. [CrossRef]

61. Hubbell, W.L.; Mchaourab, H.S.; Altenbach, C.; Lietzow, M.A. Watching proteins move using site-directed spin labeling. Structure 1996, 4, 779-783. [CrossRef]

62. Jeschke, G. Conformational dynamics and distribution of nitroxide spin labels. Prog. Nuc. Magn. Reson. Spec. 2013, 72, 42-60. [CrossRef]

63. Shah, A.; Roux, A.; Starck, M.; Mosely, J.A.; Stevens, M.; Norman, D.G.; Hunter, R.I.; El Mkami, H.; Smith, G.M.; Parker, D.; et al A Gadolinium Spin Label with Both a Narrow Central Transition and Short Tether for Use in Double Electron Electron Resonance Distance Measurements. Inorg. Chem. 2019, 58, 3015-3025. [CrossRef] [PubMed] 
64. Giannoulis, A.; Yang, Y.; Gong, Y.-J.; Tan, X.; Feintuch, A.; Carmieli, R.; Bahrenberg, T.; Liu, Y.; Su, X.-C.; Goldfarb, D. DEER distance measurements on trityl/trityl and Gd(iii)/trityl labelled proteins. Phys. Chem. Chem. Phys. 2019, 21, 10217-10227. [CrossRef] [PubMed]

65. Fleck, N.; Hett, T.; Brode, J.; Meyer, A.; Richert, S.; Schiemann, O. C-C Cross-Coupling Reactions of Trityl Radicals: Spin Density Delocalization, Exchange Coupling, and a Spin Label. J. Org. Chem. 2019, 84, 3293-3303. [CrossRef]

66. Wu, Z.; Feintuch, A.; Collauto, A.; Adams, L.A.; Aurelio, L.; Graham, B.; Otting, G.; Goldfarb, D. Selective distance measurements using triple spin labeling with $\mathrm{Gd}^{3+}, \mathrm{Mn}^{2+}$, and a nitroxide. J. Phys. Chem. Lett. 2017, 8, 5277-5282. [CrossRef]

67. Jassoy, J.J.; Berndhauser, A.; Duthie, F.; Kuhn, S.P.; Hagelueken, G.; Schiemann, O. Versatile Trityl Spin Labels for Nanometer Distance Measurements on Biomolecules In Vitro and within Cells. Angew. Chem. Int. Ed. Engl. 2017, 56, 177-181. [CrossRef]

68. Goldfarb, D. Gd ${ }^{3+}$ spin labeling for distance measurements by pulse EPR spectroscopy. Phys. Chem. Chem. Phys. 2014, 16, 9685-9699. [CrossRef] [PubMed]

69. Abdullin, D.; Schiemann, O. Localization of metal ions in biomolecules by means of pulsed dipolar EPR spectroscopy. Dalton Trans. 2021, 50, 808-815. [CrossRef]

70. Gorcester, J.; Millhauser, G.L.; Freed, J.H. In Modern Pulsed and Continuous Wave Electron Spin Resonance; Wiley: New York, NY, USA, 1990.

71. Pannier, M.; Veit, S.; Godt, A.; Jeschke, G.; Spiess, H.W. Dead-Time free measurement of dipole-dipole interactions between electron spins. J. Magn. Res. 2000, 142, 331-340. [CrossRef] [PubMed]

72. Milov, A.D.; Tsvetkov, Y.D. Double electron-electron resonance in electron spin echo: Conformations of spin-labeled poly-4vinilpyridine in glassy solutions. App. Magn. Reson. 1997, 12, 495-504. [CrossRef]

73. Joseph, B.; Morkhov, V.M.; Yulikov, M.; Jeschke, G.; Bordignon, E. Conformational cycle of the vitamin $\mathrm{B}_{12} \mathrm{ABC}$ importer in liposomes detected by Double Electron-Electron Resonance (DEER). J. Biol. Chem. 2014, 289, 3176-3185. [CrossRef]

74. Sahu, I.D.; McCarrick, R.M.; Troxel, K.R.; Zhang, R.; Smith, H.J.; Dunagan, M.M.; Swartz, M.S.; Rajan, P.V.; Kroncke, B.M.; Sanders, C.R.; et al. DEER EPR measurements for membrane protein structures via bifunctional spin labels for lipodisp nanoparticles. Biochemistry 2013, 52, 6627-6632. [CrossRef]

75. Schiemann, O.; Heubach, C.A.; Abdullin, D.; Ackermann, K.; Azarkh, M.; Bagryanskaya, E.G.; Drescher, M.; Endeward, B.; Freed, J.H.; Galazzo, L.; et al. Benchmark Test and Guidelines for DEER/PELDOR Experiments on Nitroxide-Labeled Biomolecules. J. Am. Chem. Soc. 2021, 143, 17875-17890. [CrossRef]

76. Saxena, S.; Freed, J.H. Double quantum two-dimensional Fourier transform electron spin resonance: Distance measurements Chem. Phys. Lett. 1996, 251, 102-110. [CrossRef]

77. Saxena, S.; Freed, J.H. Theory of double quantum two-dimensional electron spin resonance with application to distance measurements. J. Chem. Phys. 1997, 107, 1317-1340. [CrossRef]

78. Becker, J.S.; Saxena, S. Double quantum coherence electron spin resonance on coupled $\mathrm{Cu}(\mathrm{II})-\mathrm{Cu}(\mathrm{II})$ electron spins. Chem. Phys. Lett. 2005, 414, 248-252. [CrossRef]

79. Akhmetzyanov, D.; Ching, H.Y.; Denysenkov, V.; Demay-Drouhard, P.; Bertrand, H.C.; Tabares, L.C.; Policar, C.; Prisner, T.F.; Un, S. RIDME spectroscopy on high-spin Mn $\left({ }^{2+}\right)$ centers. Phys. Chem. Chem. Phys. 2016, 18, 30857-30866. [CrossRef]

80. Wort, J.L.; Arya, S.; Ackermann, K.; Stewart, A.J.; Bode, B.E. Pulse Dipolar EPR Reveals Double-Histidine Motif Cu(II)-NTA Spin-Labeling Robustness against Competitor Ions. J. Phys. Chem. Lett. 2021, 12, 2815-2819. [CrossRef] [PubMed]

81. Peariso, K.; Huffman, D.L.; Penner-Hahn, J.E.; O'Halloran, T.V. The PcoC copper resistance protein coordinates Cu(I) via novel S-methionine interactions. J. Am. Chem. Soc. 2003, 125, 342-343. [CrossRef]

82. Banci, L.; Bertini, I.; Ciofi-Baffoni, S.; Del Conte, R.; Gonnelli, L. Understanding copper trafficking in bacteria: Interaction between the copper transport protein CopZ and the N-terminal domain of the copper ATPase CopA from Bacillus subtilis. Biochemistry 2003, 42, 1939-1949. [CrossRef]

83. Arnesano, F.; Banci, L.; Bertini, I.; Mangani, S.; Thompsett, A.R. A redox switch in CopC: An intriguing copper trafficking protein that binds copper(I) and copper(II) at different sites. Proc. Natl. Acad. Sci. USA 2003, 100, 3814-3819. [CrossRef]

84. Meir, A.; Abdelhai, A.; Moskovitz, Y.; Ruthstein, S. EPR spectroscopy targets conformational and topological changes in the E. coli membrane fusion CusB dimer upon $\mathrm{Cu}(\mathrm{I})$ binding. Biophys. J. 2017, 112, 2494-2502. [CrossRef]

85. Su, C.-C.; Long, F.; Zimmermann, M.T.; Rajashankar, K.R.; Jernigan, R.L.; Edward, W.Y. Crystal Structure of the CusBA heavymetal efflux complex of Escherichia coli. Nature 2011, 470, 558-563. [CrossRef]

86. Su, C.-C.; Yang, F.; Long, F.; Reyon, D.; Routh, M.D.; Kuo, D.W.; Mokhtari, A.K.; Ornam, J.D.V.; Rabe, K.L.; Hoy, J.A.; et al. Crystal structure of the membrane fusion protein CusB from Escherichia Coli. J. Mol. Biol. 2009, 393, 342-355. [CrossRef]

87. Jeschke, G. MMM: A toolbox for integrative structure modeling. Protein Sci. 2018, 27, 76-85. [CrossRef] [PubMed]

88. Jeschke, G. MMM: Integrative ensemble modeling and ensemble analysis. Protein Sci. 2021, 30, 125-135. [CrossRef]

89. Krivov, G.G.; Shapovalov, M.V.; Dunbrack, R.L.J. Improved prediction of protein side-chain conformations with SCWRL4. Proteins 2009, 77, 778-795. [CrossRef]

90. Qasem, Z.; Pavlin, M.; Ritacco, I.; Gevorkyan-Airapetov, L.; Magistrato, A.; Ruthstein, S. The pivotal role of MBD4-ATP7B in the human $\mathrm{Cu}(\mathrm{I})$ excretion path as revealed by EPR experiments and all-atom simulations. Metallomics 2019, 11, 1288-1297. [CrossRef]

91. Scushan, M.; Bhattacherjee, A.; Ben-Tal, N.; Lutsenko, S. A structural model for the copper ATPase ATP7B to facilitate analysis of Wilson disease causing mutations and studies of tranport mechanism. Metallomics 2012, 4, 669-678. [CrossRef] 
92. Yu, C.H.; Yang, N.; Bothe, J.; Tonelli, M.; Nokherin, S.; Dolgova, N.V.; Braiterman, L.; Lutsenko, S.; Dmitriev, O.Y. The metal chaperone Atox1 regulates the activity of the human copper transporter ATP7B by modulating domain dynamics. J. Biol. Chem. 2017, 292, 18169-18177. [CrossRef]

93. Banci, L.; Bertini, I.; Cantini, F.; Rosenzweig, A.C.; Yatsunyk, L.A. Metal binding domains 3 and 4 of the Wilson disease protein: Solution Structure and interaction with the copper(I) chaperone HAH1. Biochemistry 2008, 47, 7423-7429. [CrossRef]

94. Holt, B.T.O.; Merz, K.M. Insights into $\mathrm{Cu}(\mathrm{I})$ exchange in HAH1 using quantum mechanical and molecular simulations. Biochemistry 2007, 46, 8816-8826. [CrossRef] [PubMed]

95. Boal, A.K.; Rosenzweig, A.C. Crystal structures of cisplatin bound to human copper chaperone. J. Am. Chem. Soc. 2009, 131, 14196-14197. [CrossRef] [PubMed]

96. De Feo, C.J.; Aller, S.G.; Siluvai, G.S.; Blackburn, N.J.; Unger, V.M. Three-Dimensional structure of the human copper transporter hCTR1. Proc. Nat. Acad. Sci. USA 2009, 106, 4237-4242. [CrossRef] [PubMed]

97. Kahra, D.; Kovermann, M.; Wittung-Stafshede, P. The C-Terminus of Human Copper Importer Ctr1 Acts as a Binding Site and Transfers Copper to Atox1. Biophys. J. 2016, 110, 95-102. [CrossRef] [PubMed]

98. Levy, A.R.; Yarmiayev, V.; Moskovitz, Y.; Ruthstein, S. Probing the structural flexibility of the human copper metallochaperone Atox1 dimer and its interaction with the CTR1 c-terminal domain. J. Phys. Chem. B 2014, 118, 5832-5842. [CrossRef]

99. Banci, L.; Bertini, I.; Cantini, F.; Massagni, C.; Migliardi, M.; Rosato, A. An NMR Study of the Interaction of the N-terminal Cytoplasmic Tail of the Wilson Disease Protein with Copper(I)-HAH1. J. Biol. Chem. 2009, 284, 9354-9360. [CrossRef]

100. Levy, A.R.; Nissim, M.; Mendelman, N.; Chill, J.; Ruthstein, S. Ctr1 Intracellular Loop Is Involved in the Copper Transfer Mechanism to the Atox1 Metallochaperone. J. Phys. Chem. B 2016, 120, 12334-12345. [CrossRef]

101. Perkal, O.; Qasem, Z.; Turgeman, M.; Schwartz, R.; Gevorkyan-Airapetov, L.; Pavlin, M.; Magistrato, A.; Major, D.T.; Ruthstein, S $\mathrm{Cu}(\mathrm{I})$ Controls Conformational States in Human Atox1 Metallochaperone: An EPR and Multiscale Simulation Study. J. Phys. Chem. B 2020, 124, 4399-4411. [CrossRef]

102. Zaccak, M.; Qasem, Z.; Gevorkyan-Airapetov, L.; Ruthstein, S. An EPR Study on the Interaction between the Cu(I) Metal Binding Domains of ATP7B and the Atox1 Metallochaperone. Int. J. Mol. Sci. 2020, 21, 5536. [CrossRef] [PubMed]

103. Meir, A.; Walke, G.; Schwerdtfeger, F.; Gevorkyan Airapetov, L.; Ruthstein, S. Exploring the role of the various methionine residues in the Escherichia coli CusB adapter protein. PLoS ONE 2019, 14, e219337. [CrossRef]

104. Von Hagens, T.; Polyhach, Y.; Sajid, M.; Godt, A.; Jeschke, G. Suppression of Ghost Distances in Multi-Spin Double ElectronElectron Resonance. Phys. Chem. Chem. Phys. 2013, 15, 5854-5866. [CrossRef]

105. Ji, M.; Tan, L.; Jen-Jacobson, L.; Saxena, S. Insights into copper coordination in the EcoRI-DNA complex by ESR spectroscopy. Mol. Phys. 2014, 112, 3173-3182. [CrossRef]

106. Hunsicker-Wang, L.; Vogt, M.; Derose, V.J. EPR methods to study specific metal-ion binding sites in RNA. Methods Enzym. 2009, 468, 335-367. [CrossRef]

107. Gamble Jarvi, A.; Bogetti, X.; Singewald, K.; Ghosh, S.; Saxena, S. Going the dHis-tance: Site-Directed Cu( $\left.{ }^{2+}\right)$ Labeling of Proteins and Nucleic Acids. Acc. Chem. Res. 2021, 54, 1481-1491. [CrossRef] [PubMed]

108. Wort, J.L.; Ackermann, K.; Giannoulis, A.; Stewart, A.J.; Norman, D.G.; Bode, B.E. Sub-Micromolar Pulse Dipolar EPR Spectroscopy Reveals Increasing Cu(II) -labelling of Double-Histidine Motifs with Lower Temperature. Angew. Chem. Int. Ed. Engl. 2019, 58, 11681-11685. [CrossRef] [PubMed]

109. Meir, A.; Lepechkin-Zilbermintz, V.; Kahremany, S.; Schwerdtfeger, F.; Gevorkyan-Airapetov, L.; Munder, A.; Viskind, O.; Gruzman, A.; Ruthstein, S. Inhibiting the copper efflux system in microbes as a novel approach for developing antibiotics. PLoS ONE 2019, 14, e0227070. [CrossRef] [PubMed]

110. Walke, G.R.; Meron, S.; Shenberger, Y.; Gevorkyan-Airapetov, L.; Ruthstein, S. Cellular Uptake of the ATSM-Cu(II) Complex under Hypoxic Conditions. ChemistryOpen 2021, 10, 486-492. [CrossRef]

111. Walke, G.R.; Ruthstein, S. Does the ATSM-Cu(II) Biomarker Integrate into the Human Cellular Copper Cycle? ACS Omega 2019, 4, 12278-12285. [CrossRef] [PubMed] 